\title{
How to retain motivated employees in their jobs?
}

\author{
Martin, Ludivine \\ LISER - Luxembourg Institute of Socio-Economic Research \\ CREM - Center for Research in Economics and Management (UMR CNRS 6211), Rennes, \\ France \\ Pre-copyedit version of the paper published in Economic and Industrial Democracy \\ 41(4), 910-953, 2020 \& First Published January 8, 2018, \\ https://doi.org/10.1177/0143831X17741528
}

\begin{abstract}
This article examines the contribution of Human Resource Management (HRM) and Information and Communication Technologies (ICT) in the retention of motivated employees. The author uses a representative random sample of private sector employees from Western Europe. The data set contains information on employees' motivations, on-the-job search and workplace environment. The results show that HRM and ICT bundles are positively related to motivations. Being motivated by intrinsic and personal growth reasons decreases the likelihood to search while being motivated by rewards or compulsion reasons increases it. HRM strengthen their likelihood to search in the same way while ICT tend to increase the likelihood to search.
\end{abstract}

\section{Keywords}

On-the-job search, work motivation, Human resource management, information and communication technologies, working conditions 


\section{Introduction}

Firms dedicate resources to increase firm-specific skills, enhance employees commitment, and stimulate collaborations and efforts with the goal of raising firm performance. The mobility of employees and especially of the most productive ones is costly for employers who want to recover their investment in human capital (Boxall and Macky, 2009; Huselid, 1995; Morrow and McElroy, 2007). Labour turnover also incurs costs due to attracting, selecting, recruiting and training new productive employees (Oi, 1962).

Earlier research has examined variables that are related to employee turnover intention. First, existing evidence underline that the turnover intention is a strong predictor of actual turnover (e.g. Böckerman and Ilmakunnas, 2009; Griffeth et al., 2000; Kristensen and WestergaardNielsen, 2006). Second, the workplace environment plays a role in the turnover intention. Nevertheless, existing researchers focus on adverse working conditions, discrimination or low social support and on specific human resource management practices such as granting voice or training (Antecol and Cobb-Clark, 2009; Böckerman and Ilmakunnas, 2009; Böckerman et al., 2013; Cottini et al., 2011; Delfgaauw, 2007; Garcia-Serrano, 2004; Green et al., 2000). Third, dissatisfied employees are those that want to quit their current job (Antecol et al., 2009; Antecol and Cobb-Clark, 2009; Böckerman and Ilmakunnas, 2009; Scott et al., 2006; Shields and Wheatley Price, 2002). However, very little is known about how the organisational and technological workplace environment can retain employees and about the type of motivations employees who are more prone to stay in their current job have. These are very important issues.

On the one hand, an important limitation of existing researches is that it puts attention on few facets of the workplace environment while it is mainly shaped by the investments of firms in Human Resource Management (HRM) practices covering participation in the organisation's

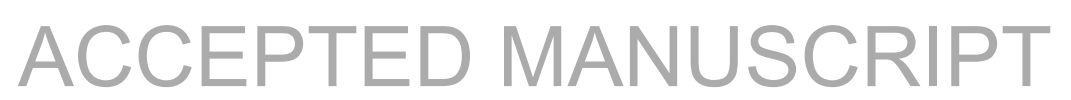


life, team working, career development, family-friendly policies and incentives, and associated Information and Communication Technologies (ICT) covering Enterprises Resources Planning, Workflow, Groupware, Intranet, Internet and email use for professional purpose. There is, in fact, a considerable consensus in the literature on the role played by HRM and ICT in firm performance (e.g. Bresnahan et al., 2002; Brynjolfsson and Hitt, 2000; Combs et al., 2006; Ichniowski et al., 1996; Ichniowski and Shaw, 2013; MacDuffie, 1995; Wu et al., 2015). Several existing studies support positive relationships between HRM, ICT and employees attitudes such as job satisfaction, organisational commitment, citizenship or pride (e.g. Böckerman et al., 2012; Brown et al., 2008; Gallie et al., 2012; Godard, 2001; Guest, 1999; Kalmi and Kauhanen, 2008; Martin and Omrani, 2015; Mohr and Zoghi, 2008; White and Bryson, 2013). The underlying assumption is that employees have a positive motivational response to HRM and ICT due to a reciprocal behaviour (Fehr et al., 1997) as sustained by various theoretical frameworks: mutual gains, social exchange theory, job demands-resources model, psychological contract and self-determination theory (Blau, 1964; Deci and Ryan, 1985; Osterman, 2000; Rousseau, 1995; Schaufeli and Bakker, 2004). Nevertheless, the relationships between HRM, ICT and individual motivations to exert effort are largely untested (except Godard, 2001; Martin, 2017) and on-the-job search behaviour (or turnover intention) is largely ignored.

On the other hand, acquiring new knowledge on the type of employees that want to stay is important as firms face higher costs of turnover if the most motivated employees that exert the higher level of effort are those that want to quit their current job. Since the work of Deci and Ryan (1985) two main types of motivations are at the centre of theories of motivation: autonomous motivation and controlled motivation. First, autonomous motivation is a desired attribute of employees for managers as they exert effort because of values, identification and intrinsic reasons and have positive behaviours at work such as cooperation, information

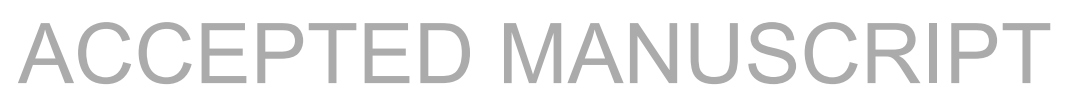


sharing, commitment, intra- and extra-role performance (Akerlof and Kranton, 2005; Gagné and Deci, 2005). Second, controlled motivation is not sought by manager as employees concerned by this type exert effort because of rewards and out of feelings of compulsion and this motivation is unrelated to positive behaviours at work except continuance commitment (i.e. staying in the current job to avoid the costs related to quit; see e.g. Kuvaas et al., 2017). Thus, to increase the quality and quantity of work effort and boost productivity, employers need to strengthen above all the autonomous motivation of the staff and to retain the most autonomously motivated employees.

The purpose of this article is to provide new evidence on on-the-job search of employees, especially motivated ones, by analysing the role of HRM practices and associated ICT. The article combines various fields of research, i.e. human resource management, organisational psychology, labour, behavioural and personnel economics that developed independently analyses on the association between the workplace environment and employee on-the-job search and contributes to fill the gap between them. Rooted in these literatures, it provides new results on how firms by investing in HRM and ICT strengthen employees motivations. Moreover, it analyses two main research questions: first, do autonomously motivated employees want to stay in their current job? Second, are they retained by their participation in HRM practices and their use of ICT?

The article is based on a representative random sample of private sector employees that is uniquely suited to examine these questions. Unlike existing data used by prior research, the studied work environment covers not only employees working conditions but also their participation in HRM practices and ICT use. Moreover, the data set contains not only job satisfaction but also work motivations as defined by self-determination theory (Deci and Ryan, 1985; 2000; Gagné and Deci, 2005; Gagné et al., 2010) and turnover intention. In addition, the data were collected recently (2013) in a Western European country characterized by the

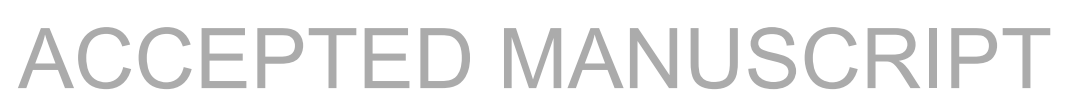


predominance of its service sector and by a multinational working population, namely Luxembourg. Hence, the article provides new results on employees working in a service economy and covers not only Luxembourgish employees but also French, Belgian, German and some other nationalities.

The article proceeds as follows. The second section discusses the related literature and hypotheses. The third section presents the data and the estimation strategy. The results are shown in the fourth section. The fifth section discusses the results and concludes.

\section{Related literature and hypotheses}

\section{The workplace environment and employees' attitudes}

Employers build their workplace environment to stimulate employees effort, increase their utility and make quits uninteresting compared to outside options. First, through the investment in their HRM strategy employers favour information sharing and provide voice channels for employees through participation activities (McGovern et al., 2007). They give more autonomy, responsibilities and discretion via team working (Gallie et al., 2012). They invest in workforce skills through development activities like trainings (Boxall and Macky, 2009). They reduce work-family conflicts through a family-friendly policy (Ernst Kossek and Ozeki, 1998). They incentivize employees by monetary and non-monetary compensations (Eriksson and Kristensen, 2014). Moreover, it has been shown that these practices are complementary, overlap each other and are mutually reinforcing. HRM practices need to be implemented through a bundle to effectively improve employees' behaviours (Böckerman et al., 2012; Bowen and Ostroff, 2004; Ichniowski et al., 1997; White and Bryson, 2013) and firm economic performance (Bowen and Ostroff, 2004; Combs et al., 2006, Godard, 2004; Wood, 1999). The underlying mechanism is that the greater the number of HRM practices adopted, the greater 
the positive results obtained by firms. The overall influence on employee behaviours will therefore depend on how intensively firms invest in HRM.

Secondly, nowadays the HRM strategy cannot be designed independently from ICT which become increasingly prevalent in workplace life. ICT are positively associated with HRM practices such as the team work or people management (Askenazy et al., 2006; Bloom et al., 2012). Adopted together HRM practices and ICT make the organisation more adaptive and increase firm performance (Askenazy et al., 2006; Bloom et al., 2014; Bresnahan et al., 2002; Brynjolfsson and Hitt, 2000; Caroli and Van Reenen, 2001; Dessein and Santos, 2006; Milgrom and Roberts, 1990). As underlined by Bloom et al. (2014), the technologies implemented to optimize the workplace environment are those that facilitate information access inside the firm (such as ERP - Enterprise Resource Planning) and those that reduce internal communication costs (such as Intranet). Moreover, Internet and e-mails strengthen the access to external information and knowledge.

To explain how the workplace environment influences employees attitudes theoretical frameworks have emerged. They focus mainly on the HRM strategy but as ICT is closely associated with, they can apply to the organisational and technological strategy built by the employer. First, in the tradition of mutual gains, the quality of the workplace environment shaped by HRM and ICT is a way of convincing employees that their work values and contribution are recognized (Batt, 2004; Kalmi and Kauhanen, 2008; Osterman, 2000). Second, in the social exchange theory, the organisational and technological strategy sets up a positive exchange relationship implying trust to which employees reciprocate (Blau, 1964). Third, in the job demands-resources model, while demands are the "things that have to be done" (Schaufeli and Bakker, 2004, p. 296), HRM practices and ICT can act as resources to reduce job demands costs and stimulate employees' personal growth. Fourth, according to the psychological contract perspective (Rousseau, 1990; 1995; Sturges et al., 2005), the

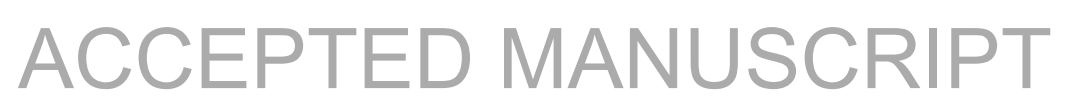


organisational and technological strategy shapes the psychological contract by influencing employee and employer promises fulfilment (Suazo et al., 2009). Through the investment in their organisational and technological strategy, employers indeed create a positive workplace environment that reflects how they see their employees. Investing in employees, giving voice, trust, and reducing work-family conflicts inherently involve long-term relationship and reveal that their employer see employees as being part of its permanent staff fulfil the relational part of the psychological contract. Monetary and non-monetary incentives (Eriksson and Kristensen, 2014), that are in essence targeted and available on short-term fulfil the transactional part of the psychological contract. Fifth, the organisational and technological strategy by giving employees responsibilities via team working, raising their competence through trainings and social affiliation via participation practices such as meeting between management and the staff and coordinating ICT tools also echoes to the Self-Determination Theory (Deci and Ryan, 1985). By fulfilling the satisfaction of the three basic psychological needs for autonomy, competence and social affiliation, HRM practices and ICT should improve the employees' motivations and other attitudes (Baard et al., 2004; Marescaux et al., 2013).

The main underlying assumption in all theoretical frameworks is that employees reciprocate to the positive workplace environment built by their employer. Moreover, it is well established with both survey and experimental data that reciprocity is a motivating factor for employees (e.g. Fehr et al., 1997; Gould-Williams, 2007).

Based on these theoretical frameworks, the following hypothesis is proposed:

Hypothesis 1. The organisational and technological strategy is positively associated with employees' reciprocity. 
The relationship between the workplace environment and on-the-job search behaviour

A major stream of empirical research on labour turnover has examined employees turnover intentions. While, it has been shown that management practices lead to lower firm-level quit rates (Batt et al., 2002; Haines et al., 2010; Huselid, 1995) and encourage non-performers to leave the firm (Jones and Wright, 1992), existing empirical research puts attention on only few facets of the workplace environment. Scholars indeed focus on either working conditions, or specific management practices. First, it has been shown that adverse working conditions (such as harm, hazard), poor promotion prospects, discrimination and low social support are positively related to employees on-the-job search (Böckerman et al., 2013; Griffeth et al., 2000). Second, scholars that studied human resource management practices focus on specific practices. Cottini et al. (2011) underline that granting voice to employees decreases their probability of voluntary turnover. Green et al. (2000) show that training provided by employers decreases the employee turnover intention. Marescaux et al. (2013) observe that training, career development, direct employee participation and developmental appraisal are negatively related with turnover intention of employees. Garcia-Serrano (2004) shows that autonomy, participation in firm life, including training and knowledge about the objectives of the firm diminish turnover intentions. Delfgaauw (2007) points out that dissatisfaction in relation to autonomy, responsibility, financial prospects, training and organisational management increases the on-the-job search of public sector employees.

Empirical evidence on HRM practices taken as a bundle underlines positive links with employee attitudes such as job satisfaction, organisational commitment, involvement, organisational citizenship, pride or motivations (Bauer, 2004; Böckerman et al., 2012; Brown et al., 2008; Gallie et al., 2001; 2012; Godard, 2001; Guest, 1999; Kalmi and Kauhanen, 2008; Macky and Boxall, 2007; Martin, 2017; Martin and Omrani, 2015; Mohr and Zoghi, 2008; Ramsay et al., 2000; White and Bryson, 2013). The analysis of the relationship between the 
HRM strategy and on-the-job search that is largely ignored in exiting studies constitutes one of the contributions of the article to the literature.

Regarding ICT, only the linkage of employee behaviours with few technologies used at work have been already examined in the literature mostly computer, Internet and e-mail uses (Gallie et al., 2001; Mohr and Zoghi, 2008; Martin, 2017; Martin and Omrani, 2015). In the most recent studies, Internet and e-mail appear to be positively linked with employees attitudes such as job satisfaction and extra-effort (Martin and Omrani, 2015) and also workflow and Intranet with intrinsic motivation whereas groupware is negatively related to intrinsic motivation (Martin, 2017). Moreover, an increase use of ICT for work purposes may also be associated with the blurring of work-life boundaries and stress. Positive relationships between ICT and work-family conflict or stress (especially e-mail use) have indeed been underlined (e.g. Fenner and Renn, 2010; Mark et al., 2016; Schieman and Young, 2013). Moreover, in the tradition of skill-biased technological change literature, technological changes are biased toward skilled employees (Bauer and Bender, 2004; Bresnahan et al., 2002; Caroli and Van Reenen, 2001; Chennels and Van Reenen, 2002).

The assessment of the relationship between ICT and on-the-job search that is untested in exiting studies constitutes another contribution of the article to the literature.

Based on empirical evidence, I hypothesize the following:

Hypothesis $2 a$. Turnover intention is expected to be negatively related to HRM.

Hypothesis $\mathbf{2 b}$. The relationship between ICT and turnover intention is indeterminate. 
As motivated employees are those who provide a high degree of effort that is needed to increase firm performance (e.g. Gagné and Deci, 2005), it is, thus, important to study their turnover intention and it constitutes one of the contributions of the article.

Specifically, social psychology research, grounded on self-determination theory (Deci and Ryan, 2000), provides a theory that defines sources of motivation and the role of each type in individual development. Two main types of work motivation are distinguished: autonomous motivation and controlled motivation. The first type covers not only the intrinsic motivation i.e. performing an activity for its own interest but also identified regulation i.e. exerting effort due to identification with job value, or alignment with individual goals. The second type encompasses not only the extrinsic motivation i.e. exerting effort to obtain a reward or avoid a sanction but also the introjected regulation i.e. performing a task due to self-worth contingencies. Researchers in the tradition of the self-determination theory and models of behavioural economics reveal that autonomous motivation is associated with employees positive behavioural outcomes such as affective commitment, intra and extra-role performance (see the reviews by Gagné and Deci, 2005 and Kuvaas et al., 2017). They suggest that "autonomous motivation [...] is superior in situations that include both complex tasks that are interesting and less complex tasks that require discipline. When a job involves only mundane tasks, however, there appears to be no performance advantage to autonomous motivation" (Gagné and Deci, 2005: page 347). Thus, for all tasks except mundane tasks, autonomous motivation dominates controlled motivation in term of performance. Gómez-Miñambres (2012) shows that intrinsic motivation leads individuals to achieve their highest productivity. Minkler (2004) underlines that autonomous forms of motivation increase the likelihood of keeping to the contract of best effort. 
On the contrary, as shown by Kuvaas et al. (2017) and Gagné et al. (2010) the only employee behaviours positively correlated with controlled motivation is continuance commitment (i.e. staying in the current organisation "to avoid costs associated with leaving", Meyer et al., 2002: page 39). The relationship between controlled motivation and individual work performance is indirectly highlighted in the literature. Behavioural economics experiments reveal indeed that it is for uninteresting tasks that do not embedded autonomous motivation such as simple, standardized and easily rewardable tasks that there is a positive effect of monetary incentives on performance suggesting that controlled motivation matters for such tasks (Bareket-Bojmel et al., 2014; Weibel et al., 2010). As many current job in industrialized countries are not based on strictly defined and quantifiable measures of individual performance but are much more multidimensional and not completely undertaken by each individual alone the link with individual work performance can be negative. Kuvaas et al. (2017) show indeed that in two business activities (gas stations and financial companies) extrinsic motivation is negatively related to individual work performance and affective commitment. In this context, this type of motivation even if it is not necessarily bad, will not be a highly desired attribute for the employer.

Therefore, it is fundamental for employers to stimulate work motivation and preferably the autonomous form and to find a way to retain autonomously motivated employees through the investments in HRM and ICT. Nevertheless, the role of the workplace organisational and technological environment in strengthening employees' motivation remain largely untested. Godard (2001) without disentangling the type of motivation shows that an intensive participation in HRM practices is positively related to motivation. Martin (2017) provides some interesting results on how HRM practices and ICT can influence employees' motivations but provides no results on turnover intention. Employees with high autonomous motivation (intrinsic motivation or identified regulation) are motivated by HRM practices that satisfies

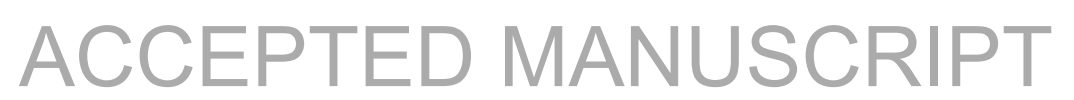


one of the three basic psychological needs of autonomy (e.g. flexible work time, telework, team working), competence (through trainings) and social affiliation (e.g. team working, formal appraisal) and an intensive participation is also positively related. Technologies that reduce the cost to communicate and to access to information (Workflow, Intranet, Internet, e-mail but not groupware) are positively related to autonomous motivation and an intensive use is also positively related. Employees with high controlled motivation (external or introjected regulation) focus more on the transactional part of the psychological contract with their employer. They indeed positively react to monetary incentives, but also to HRM practices that can be linked to potential sanction directly via the manager, i.e. formal appraisal or indirectly via peers in team working. Technologies related to a reduction of the cost to access to information such as Workflow and Internet are positively related to controlled motivation and an intensive use is slightly positive.

Based on empirical evidence, I hypothesize the following:

Hypothesis 3. HRM and ICT are positively related to employees' motivations.

Moving on to the turnover intention by type of employees, since the seminal work of Freeman (1978) and Akerlof et al. (1988), the literature on turnover intention puts a large amount of emphasis only on dissatisfied employees. They underline that job dissatisfaction is a good predictor of turnover intentions or actual separation (Clark et al., 1998; Clark, 2001; Delfgaauw, 2007; Green, 2010; Kristensen and Westergaard-Nielsen, 2006; Lévy-Garboua et al., 2007; Pissarides and Wadsworth, 1994; Sousa-Poza and Henneberg, 2004). From these previous researches, it is well established that dissatisfied employees have a higher willingness to quit their current employer.

Gagné and Deci (2005) and Karasek and Theorell (1990) argue that motivated employees have lower turnover intentions, especially those that are autonomously motivated but do not provide 
empirical evidence. ${ }^{1}$ The underlying hypothesis is that beyond the increase of individual performance, autonomous motivation energizes employees and protects them against stress and negative emotions (Gagné et al., 2010). Focusing on intrinsic motivation, Dysvik and Kuvaas (2008; 2010) and Kuvaas et al. (2017) show on data collected in specific business sectors (medical technology, finance, services or industries) that this motivation reduce employee turnover intention.

In the self-determination theory tradition, employees motivated by controlled motivation act to obtain rewards and avoid punishment that can negatively affect negatively their emotional and psychological states. Focusing on extrinsic motivation, Gagné et al. (2010) show that for correctional officers working at a Canadian prison this motivation is positively related to psychological distress. Lemyre et al. (2007) underline that extrinsically motivated elite athletes are more susceptible to burnout. Kuvaas et al. (2017) or Vansteenkiste et al. (2007) (on administrative staff of a community) reveal that extrinsic motivation or extrinsic work-value orientation are positively associated with turnover intention. Hence, the following hypotheses are proposed:

Hypothesis 4a. Autonomous motivation is negatively related to turnover intention.

Hypothesis 4b. Controlled motivation is positively related to turnover intention.

Whereas the relationships between organisational and technological practices and motivation or turnover intention have been the object of some empirical analyses, the links between the workplace environment and turnover intentions of motivated employees remain untested. It constitutes another contribution of the article to the literature. Nevertheless, grounded on the literature related to the workplace environment and employees' motivation and turnover

\footnotetext{
${ }^{1}$ Some scholars also provide evidence for the negative links between a concept related to motivations, i.e. organisational commitment and turnover intention (Meyer et al., 2002; Mowday et al., 1982).
} 
intention and hypotheses $2 \mathrm{a}$ and $2 \mathrm{~b}$, autonomously motivated employees are those that should positively react to the positive organisational workplace environment built by their employer. And the organisational workplace environment should strengthen their willingness to stay. Depending on the weight of the perverse effects of ICT compared to their benefits, the technological environment can be positively, negatively or neutrally related to their turnover intention. For employees with controlled motivation, as they stay in a job for necessity reasons, and are subject of negative emotions and psychological distress, it is not easy to determine if the organisational and technological workplace environment thwart or reinforce the positively relationship with turnover intention stated in Hypothesis $4 \mathrm{~b}$.

The following hypotheses are proposed:

Hypothesis 5a. For autonomous motivation, the organisational workplace environment is negatively related to turnover intention.

Hypothesis 5b. For controlled motivation, the relationships between the organisational workplace environment and turnover intention is indeterminate.

Hypothesis 5c. The relationships between the technological workplace environment and turnover intention related to employees' motivations are indeterminate.

\section{Empirical strategy}

\section{Data}

The opportunity to conduct this analysis is given by an original data set coming from the 'Survey on working conditions and quality of work life' (QVT) collected in 2013 by LISER on behalf of the National Social Security Ministry in line with the guidelines provided by the MEADOW Consortium (2010). The representative random sample was drawn from the exhaustive administrative data of the national social security. A stratified sampling strategy, on

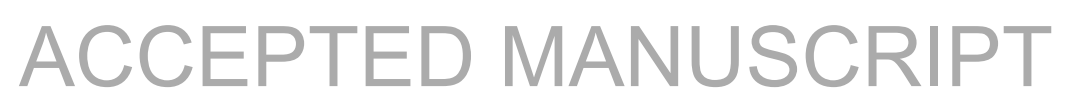


employees working in Luxembourg aged at least 15 years, was used in order to ask at least one employee for all organisations in the private sector with at least 15 employees. The noncompulsory survey was conducted online between March and June 2013 in four countries (Luxembourg, Belgium, France and Germany) and 3 languages (French, German and English). Approximately 60,000 employees were surveyed and around 26 percent participated. Because of job switching between the time of the sample drawing and the conduct of the survey, missing information on a large part of survey items for some respondents and the exclusion of employees with less than twelve months of tenure in the current organisation, the final sample size came to 14,248 employees. The data set was supplemented with administrative data from the national social security to characterize the firm in which the employee works. Observations are weighed to ensure that the distributions by country of residence, nationality, gender, age, white and blue collars, economic activity and size class of the firm in which the employee works are representative of people at work in the private sector, whether they are resident (about $47 \%$ of the working population) or cross-border employees (about $53 \%$ of the working population). Thus, the results do not concern only Luxembourgish employees (18\% of the studied population) but also employees from other nationalities: French (31\%), Belgian (15\%), Portuguese (14\%), German (13\%) and another nationality (9\%). It should be noted that the Luxembourgish labour market offers the best employment opportunities for cross-border employees (at least in terms of wages and labour market dynamics) comparted to the crossborder labour markets. Like most of existing data used to study the workplace environment, employees attitudes and on-the-job search, the data are cross sectional, thus, the analysis tests the strength of conditional correlations and not causal relationships.

\section{Measuring motivations}

The survey includes the Motivation at Work Scale (MAWS) developed and validated by Gagné et al. (2010) based on the self-determination theory (Deci and Ryan, 1985; 2000). It covers the

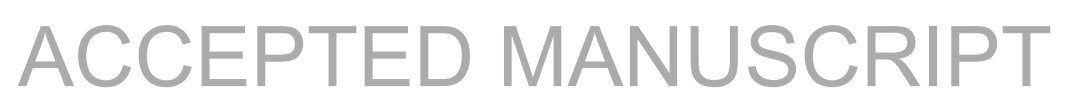


spectrum of work motivation. Employees exert effort because the tasks are interesting and enjoyable (intrinsic motivation), because the job corresponds to their values and goals (identified regulation) or because of guilt or to maintain their self-esteem (introjected regulation) and, in addition, to obtain rewards (external regulation). The eleven separate items covering this spectrum are summarized in Table 1. Factor analysis is used to create a measure of employee work motivation based on the number of meaningful common factors. As shown in Figure 1, the factor analysis indicates that the first factor describes the average employee position on the spectrum of motivation because it affects the responses to all items positively. The second factor separates autonomous motivations (identified regulation and intrinsic motivation) from controlled motivations (external and introjected regulation), which is consistent with the research in conceptualizing motivations (Deci and Ryan, 2000; Gagné et al., 2010). The variable 'External_1' is not well explained by the two factors (uniqueness above 0.7) and is discarded. The consistency of Cronbach's alpha ( $\alpha$ in Table 1) is good for autonomous motivation and acceptable for the controlled motivation (Hair et al., 2006). The indexes used in the empirical analyse are constructed as described in Table 1 and are standardized via z-score (i.e. by subtracting the mean and dividing by standard deviation).

Table 1. Components of work motivation indexes.

\begin{tabular}{|c|c|c|c|c|}
\hline $\begin{array}{l}\text { Variable } \\
\text { name }\end{array}$ & Measurement & Mean & Std. dev. & Median \\
\hline External_1 & $\begin{array}{l}\text { Because of sanctions (being fired } \\
\text { because of low effort) }\end{array}$ & 5.06 & 3.39 & 5 \\
\hline External_2 & Because of the pay-check & 6.54 & 2.89 & 7 \\
\hline External_3 & $\begin{array}{l}\text { Because it allows me to get rewards } \\
\text { (bonuses or promotion) }\end{array}$ & 3.87 & 3.40 & 4 \\
\hline Introjected_1 & $\begin{array}{l}\text { Because otherwise I feel bad about } \\
\text { myself }\end{array}$ & 6.91 & 3.15 & 8 \\
\hline Introjected_2 & $\begin{array}{l}\text { Because I have to prove to myself that I } \\
\text { can do it }\end{array}$ & 5.86 & 3.35 & 7 \\
\hline Introjected_3 & Because my reputation depends on it & 5.21 & 3.39 & 6 \\
\hline Identified_1 & Because this job fulfils my career plans & 4.59 & 3.17 & 5 \\
\hline Identified_2 & $\begin{array}{l}\text { Because it allows me to reach my } \\
\text { personal goals }\end{array}$ & 4.83 & 3.32 & 5 \\
\hline Identified_3 & Because this job fits my personal values & 5.37 & 3.19 & 6 \\
\hline
\end{tabular}




\begin{tabular}{|c|c|c|c|c|}
\hline Intrinsic_1 & Because I have fun doing my job & 6.63 & 2.89 & 7 \\
\hline Intrinsic_2 & Because my job is stimulating & 5.11 & 3.07 & 5 \\
\hline $\begin{array}{l}\text { Overall work } \\
\text { motivation } \\
\alpha=0.84\end{array}$ & $\begin{array}{l}\text { Index based on the } 10 \text { items retained: } \\
M(i)=\sum_{j=1}^{10} c 1_{j} x_{j}(i) ; \text { where } c 1_{j} \text { gives } \\
\text { the coordinates of the items on the first } \\
\text { factor and } x_{j}(i) \text { the values taken by the } \\
\text { responses given by each employee (i) to } \\
\text { the items }\end{array}$ & 31.93 & 12.83 & 33 \\
\hline $\begin{array}{l}\text { Controlled } \\
\text { motivation } \\
\alpha=0.67\end{array}$ & $\begin{array}{l}\text { Similar formula based on the } 5 \text { items of } \\
\text { controlled motivation revealed by the } \\
\text { second factor }\end{array}$ & 12.51 & 5.04 & 13 \\
\hline $\begin{array}{l}\text { Autonomous } \\
\text { motivation } \\
\alpha=0.88\end{array}$ & $\begin{array}{l}\text { Similar formula based on the } 5 \text { items of } \\
\text { autonomous motivation revealed by the } \\
\text { second factor }\end{array}$ & 19.42 & 9.38 & 21 \\
\hline Observations & & 14,248 & & \\
\hline
\end{tabular}

Notes: Weighted statistics. Descriptive statistics and Cronbach's alpha $(\alpha)$ are prior to standardization. The related question in the survey is "Using a scale from 0 to 10 , please indicate from the following statements to what extent they apply to you. I dedicate myself to my work...”.

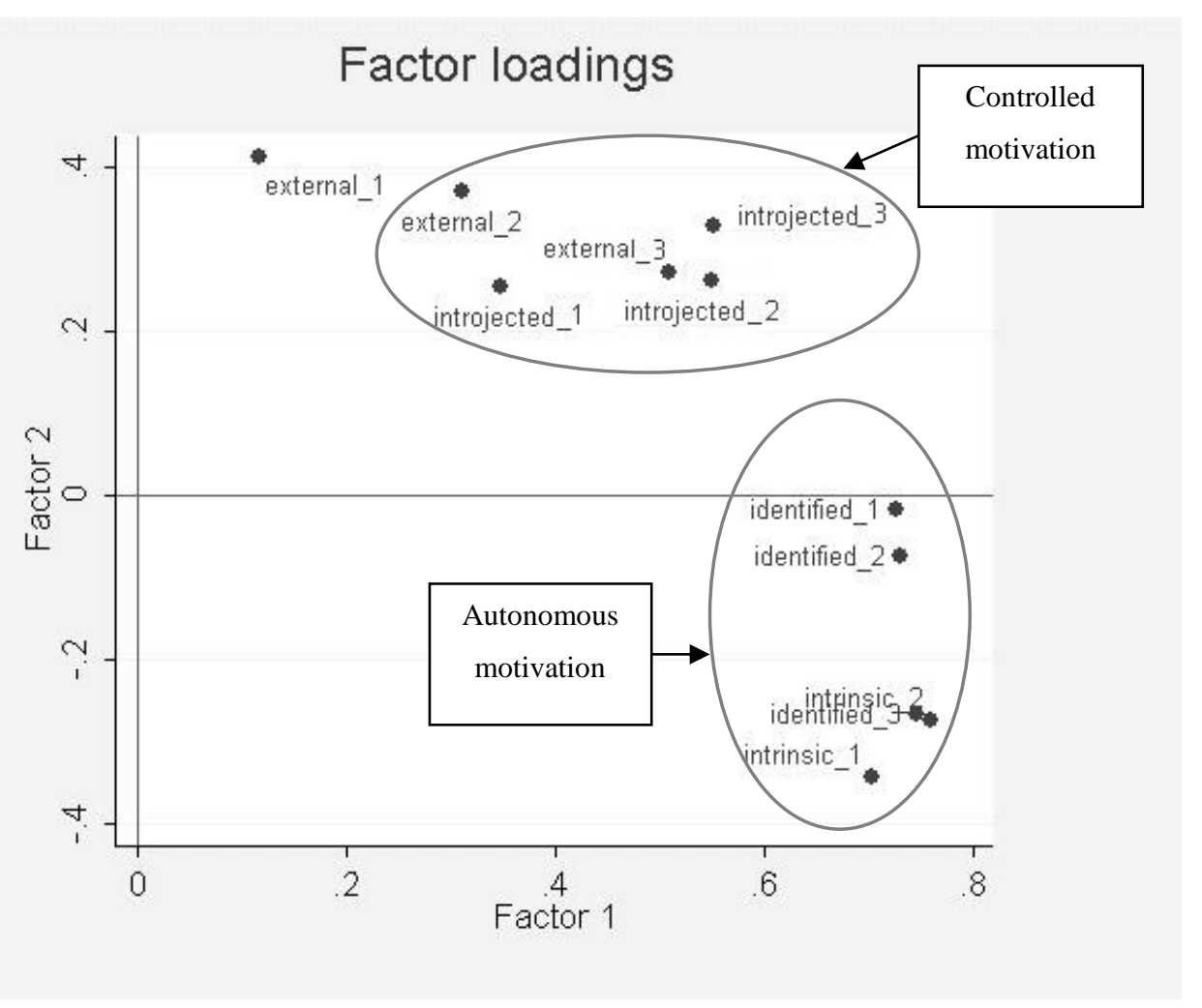

Figure 1. Factor loading of the work motivation items.

Reading guide: The work motivation items labels are described in Table 1. Factor 1 describes the spectrum of motivation. Factor loadings of Factor 2 reveals the distinction between the two clouds of motivation items, i.e. controlled motivation and autonomous motivation while 'external_1' (motivated because of sanctions) is excluded. 
Work motivation and on-the-job search behaviour

Empirical evidence revealed by social psychology research show that for all tasks undertaken by employees (except mundane ones) autonomous forms of motivation are associated with positive attitudes and better performance compared with controlled motivation (Gagné and Deci, 2005; Kuvaas et al., 2017). From a managerial point of view, it is thus fundamental for employers to retain autonomously motivated employees while encouraging non-motivated employees and those motivated by external reasons to leave.

The data set gives no information on actual turnover but as shown by Böckerman and Ilmakunnas (2009) and Kristensen and Westergaard-Nielsen (2006), on-the-job search is a strong predictor of actual turnover. The on-the-job search behaviour measure is close to those of Delfgaauw (2007): 'Have you tried to leave your current job in the last 12 months?' with three possible answers 'No, not at all', 'Yes, I have been looking around', 'Yes, I have intensively searched'. As only less than $6 \%$ of the weighted sample declared the third answer, a dummy variable of on-the-job search was constructed and grouped together the two last answers (32.6\% of the weighted sample).

\section{Participation in HRM practices and use of ICT}

The studied organisational environment of the employee is in line with papers that analysed how management practices permits to enhance employees attitudes such as job satisfaction, organisational commitment, motivations, citizenship or pride but in which turnover intentions are largely ignored (e.g. Bauer, 2004; Böckerman et al., 2012; Brown et al., 2008; Gallie et al., 2012; Godard, 2001; Guest, 1999; Kalmi and Kauhanen, 2008; Martin, 2017; Martin and Omrani, 2015; Mohr and Zoghi, 2008; White and Bryson, 2013). Based on the bundle view supporting synergistic benefits between HRM practices, the participation of the employee in

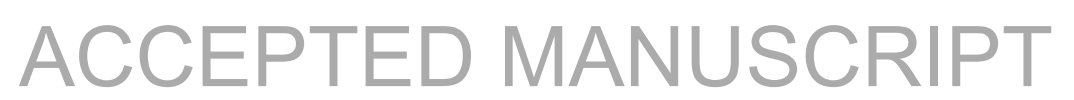


management practices is captured by a score or bundle of practices. The practices summed in the HRM bundle cover the following domains: participation ${ }^{2}$, team working, development, family-friendly policy, and incentives. The technologies used by employees studied are the very ones that have been shown to be implemented by employers to optimize their workplace environment (Bloom et al., 2014): technologies that facilitate internal information access (ERP - Enterprise Resource Planning, workflow) and technologies that reduce internal communication costs (groupware, Intranet). ICT that favour external access to information and knowledge are also included (Internet and e-mail). They are measured at the employee level and summed up to calculate the ICT bundle. Appendix Tables A1 and A3 give the descriptive statistics of the HRM practices and ICT included and the distribution of the bundles. Appendix Tables A2 and A4 show the distribution of the percentage of employees concerned by a HRM practice or an ICT depending for all levels of each bundle. The HRM practices that concern the most employees in the highest level of the HRM bundle are meeting between management and the staff, attitudes surveys, quality circle, quality norms, development policy, training, formal appraisal, flexible work time, work-life balance and fringe benefits. The HRM practice that concerns the most employees in the lowest level is job rotation. For the ICT bundle, the technologies that concern most employees in the highest level are ERP, Workflow, Groupware, Intranet and email use for professional purpose.

An interaction term between the two bundles is also studied (specification 2 in the empirical strategy). It captures the parallel diffusion of management practices and ICT in organisations

\footnotetext{
${ }^{2}$ The low degree of participation in decisions concerning major changes within their firm observed in Table 1 can be explained by the fact that, by law, firms with at least 15 employee (those covered in the sample) need to have a staff delegation. It is the consultation body of the firm and consists of seven members who are elected for a fiveyear term. Employers have the duty to inform the staff delegation about the economic and financial developments and recent and future activities of the firm and to consult and inform the staff delegation on issues relating to working conditions.
} 
that can have an additional association with employees' motivations and on-the-job search behaviour.

\section{Control variables}

Since individual, job and organisation characteristics could affect the results of the analysis careful control variables are introduced. In line with existing research on job dissatisfaction and turnover intentions, adverse working conditions that can influence employees' motivations are included (Antecol et al., 2009; Antecol and Cobb-Clark, 2009; Böckerman and Ilmakunnas, 2009; Böckerman et al., 2013; Scott et al., 2006, Shields and Weathley Price, 2002). In line with existing evidence that underlines the role played by outside opportunities in employees utility in the current job and turnover intentions, measures of outside opportunities are also included (Antecol and Cobb-Clark, 2009; Böckerman and Ilmakunnas, 2009; Clark and Oswald, 1996; Green, 2010 or Theodossiou and Zangelidis, 2009). The quality of the match between the employee and the current job that can also influence employees attitudes and search decisions are included (Boxall, 2013; Van Ophem, 1991). ${ }^{3}$ Information about these variables is provided in Appendix Table A5.

\section{Estimation strategy}

A model inspired by Antecol and Cobb-Clark (2009) and Böckerman and Ilmakunnas (2009) constitutes the estimation strategy. It investigates, in a first part, the relationships between employees participation in the HRM strategy of the employer, use of ICT and work motivation. In a second part, the associations between employees' motivations and on-the-job search are estimated taking into account the role played by HRM and ICT. This model is recursive in the

\footnotetext{
3 It has been shown in the literature that work organisational practices are complementary to skills and that technological changes are skill-biased (Bauer and Bender, 2004; Bresnahan et al., 2002; Caroli and Van Reenen, 2001; Chennels and Van Reenen, 2002). Measures of matching quality concerning skills; educational level and occupations are included to control for skills in the estimates.
} 
sense that work motivation(s) explains on-the-job search but on-the-job search does not explain work motivation(s). In a first model, only one equation for the overall work motivation index is introduced $(M)$. In a second model that disentangles controlled motivation $(C M)$ and autonomous motivation $(A M)$ two equations are introduced.

A model written as follows is estimated (for Model 2 - specification 2):

$$
\left\{\begin{array}{cclll}
S_{i}^{*}= & \alpha_{1} C M_{i}+\beta_{1} A M_{i}+\gamma_{1} H_{i} * C M_{i}+\varphi_{1} H_{i} * A M_{i}+ & \delta_{1} H_{i}+\pi_{1} I_{i}+\omega_{1} H_{i} * I_{i}+\tau_{1} X_{i} & & +\varepsilon_{1 i}^{S} \\
C M_{i}= & & \delta_{2} H_{i}+\pi_{2} I_{i}+\omega_{2} H_{i} * I_{i}+\tau_{2} X_{i} & +\vartheta_{2} Z_{i} & +\varepsilon_{2 i}^{C M} \\
& & \delta_{3} H_{i}+\pi_{3} I_{i}+\omega_{3} H_{i} * I_{i}+\tau_{3} X_{i} & +\vartheta_{3} Z_{i} & +\varepsilon_{3 i}^{A M}
\end{array}\right.
$$

where $i$ indexes the employee, $S_{i}^{*}$ is the unobserved (latent) measure of on-the-job search behaviour, $C M_{i}$ and $A M_{i}$ measures controlled motivation and autonomous motivation, respectively. $H_{i}, I_{i}$ are respectively the HRM bundle and ICT bundle observed at the employee level and $H_{i} * I_{i}$ the interaction term between the two bundles. In specification 2, interaction variable(s) between work motivation measure(s) and HRM bundle $\left(H_{i} * C M_{i}+H_{i} * A M_{i}\right)$ are added. Further, $X_{i}$ includes adverse working conditions variables, outside opportunities proxies, matching quality indicators and other control variables about employee, job and organisation characteristics (and a constant) included in all models and $Z_{i}$ are the instruments, described below, which are only included in the motivation equation(s) as the exclusion restriction. $\varepsilon_{i}^{C M}, \varepsilon_{i}^{A M} \varepsilon_{i}^{S}$ are random errors normally distributed.

Because of the potential behavioural correlations between being motivated and searching for another job, an instrumenting strategy is implemented. Identification and consistent estimation of the above model depend on the lack of correlation between, on the one hand, potentially endogenous motivations and, on the other hand, the error term of the on-the-job search equation, or on the availability of instruments correlated with potentially endogenous motivations and uncorrelated with the error terms of the on-the-job search equation. The choice 
of instruments has empirical and theoretical appeals (Deci and Ryan, 1985; Gagné and Deci, 2005; Gagné et al., 2010). Based on the self-determination theory and empirical results on it and beyond the HRM practices covered by the HRM strategy, task discretion, work dependence with colleagues, feedback from the superior, quintile of hourly wages that can be sources of the three basic psychological needs of autonomy, competence and social affiliation that must be fulfilled to support motivation and are not supposed to be related to the error term of the onthe-job search equation are used as instruments. Following Antecol and Cobb-Clark (2009), the validity of this exclusion restriction is explored by using 2SLS that estimate independently a linear probability specification of on-the-job search using sources of basic needs as excluded instruments and motivation indexes as endogenous. Appendix Table A6 provides indicative tests for Model 2 - Specification 2 (disentangling controlled and autonomous motivations). The $F$-statistics from the first-stage regressions exceed 10 which is indicative that weak instruments are not a particular concern (Staiger and Stock, 1997). The over-identification tests reveal that the excluded instruments are not incorrectly omitted from the estimation equation of on-thejob search (Baum et al., 2007).

The two or three equations (depending on the model of the estimation strategy) form a system of continuous (motivation indexes) and binary (on-the-job search) dependent variables with potentially endogenous explanatory variables (motivations). It is assumed that all equations include unobserved heterogeneity and therefore the error terms of the two (or three) equations are allowed to be correlated. Because of the recursive structure and assuming normally distributed errors, the model is estimated using the conditional recursive mixed process estimator based on the Geweke-Hajivassiliou-Keane (GHK) simulated maximum likelihood estimator implemented in Stata by Roodman (2011). Moreover, the model is estimated with robust standard errors that are clustered at the firm level to correct for the fact that some 
employees are employed by the same employer and therefore the observations may not be entirely independent.

\section{Results}

The main results are summarized in Table 2. ${ }^{4}$ Two models are estimated and vary only at the level of motivation measures: (i) the first model includes the overall work motivation index (M), (ii) the second model disentangles controlled motivation (CM) from autonomous motivation (AM). For each model, Table 2 reports two specifications, specification 1 including work motivation measures, HRM bundle, ICT bundle and an interaction variable between the two, and in specification 2 interaction variable(s) between work motivation measure(s) and HRM bundle are added to deepen the analysis of how the HRM and ICT strategy permits to retain or push towards the exit employees. The average marginal effects are reported for onthe-job search (which is estimated with a probit model in the system of equations) in columns (2), (4), (7) and (10) while other columns report coefficients (which are estimated with continuous maximum likelihood estimators).

Correlation coefficients between the error terms of all equations are given at the bottom of Table 2. Significant correlation terms between errors terms of the equations suggest that unobserved heterogeneity across equations lead to bias results obtained with independent regressions. In particular, there is a positive and significant correlation between the error terms of autonomous motivation and on-the-job search equations while the correlation is significant and negative between controlled motivation and on-the-job search equations.

\footnotetext{
${ }^{4}$ The results of all variables included in all models of Table 2 are available in Appendix Table A7.
} 
Table 2. HRM, ICT, work motivation and on-the-job search.

\begin{tabular}{|c|c|c|c|c|c|c|c|c|c|c|}
\hline & \multicolumn{4}{|l|}{ Model 1} & \multicolumn{6}{|l|}{ Model 2} \\
\hline & \multicolumn{2}{|c|}{ Specification 1} & \multicolumn{2}{|c|}{ Specification 2} & \multicolumn{3}{|c|}{ Specification 1} & \multicolumn{3}{|c|}{ Specification 2} \\
\hline & $\begin{array}{l}\text { Overall } \\
\text { work } \\
\text { moti- } \\
\text { vation } \\
\end{array}$ & $\begin{array}{l}\text { On-the- } \\
\text { job } \\
\text { search }\end{array}$ & \begin{tabular}{|l|} 
Overall \\
work \\
motiv- \\
ation \\
\end{tabular} & $\begin{array}{l}\text { On-the- } \\
\text { job } \\
\text { search }\end{array}$ & $\begin{array}{l}\text { Control- } \\
\text { led moti- } \\
\text { vation }\end{array}$ & $\begin{array}{l}\text { Autono- } \\
\text { mous } \\
\text { motiva- } \\
\text { tion }\end{array}$ & $\begin{array}{l}\text { On-the- } \\
\text { job } \\
\text { search }\end{array}$ & $\begin{array}{l}\text { Control- } \\
\text { led moti- } \\
\text { vation }\end{array}$ & $\begin{array}{l}\text { Autono- } \\
\text { mous } \\
\text { motiva- } \\
\text { tion }\end{array}$ & $\begin{array}{l}\text { On-the- } \\
\text { job } \\
\text { search }\end{array}$ \\
\hline & (1) & (2) & (3) & (4) & (5) & (6) & (7) & (8) & (9) & $(10)$ \\
\hline $\begin{array}{l}\text { Overall work } \\
\text { motivation (M) }\end{array}$ & & $\begin{array}{l}-0.10 * * * \\
(0.016)\end{array}$ & & $\begin{array}{l}-0.09 * * * \\
(0.019)\end{array}$ & & & & & & \\
\hline $\begin{array}{l}\text { Controlled } \\
\text { motivation }(\mathrm{CM})\end{array}$ & & & & & & & $\begin{array}{l}0.24 * * * \\
(0.0378)\end{array}$ & & & $\begin{array}{l}0.21 * * * \\
(0.0405)\end{array}$ \\
\hline $\begin{array}{l}\text { Autonomous } \\
\text { motivation (AM) }\end{array}$ & & & & & & & $\begin{array}{l}-0.22 * * * \\
(0.0174)\end{array}$ & & & $\begin{array}{l}-0.18 * * * \\
(0.0222)\end{array}$ \\
\hline HRM bundle $(\mathrm{H})$ & $0.12 * * *$ & $-0.02 * * *$ & $0.12 * * *$ & $-0.02 * * *$ & $\begin{array}{l}0.084 * * \\
*\end{array}$ & $0.12 * * *$ & $-0.02 * * *$ & $0.08 * * *$ & $0.12 * * *$ & $-0.02 * * *$ \\
\hline $\mathrm{H}^{* \mathrm{M}}$ & $(0.0063)$ & $(0.0040)$ & $(0.0063)$ & $\begin{array}{l}(0.0042) \\
-0.003 * \\
(0.0017)\end{array}$ & $(0.0066)$ & $(0.0062)$ & $(0.0033)$ & $(0.0066)$ & $(0.0062)$ & $(0.0034)$ \\
\hline $\mathrm{H}^{*} \mathrm{CM}$ & & & & & & & & & & $\begin{array}{l}0.004 * * \\
*\end{array}$ \\
\hline $\mathrm{H}^{*} \mathrm{AM}$ & & & & & & & & & & $\begin{array}{l}(0.0015) \\
-0.01 * * * \\
(0.0017)\end{array}$ \\
\hline ICT bundle (I) & $0.06^{* * *}$ & $0.04 * * *$ & $0.06^{* * *}$ & $0.04 * * *$ & $\begin{array}{l}0.057 * * \\
*\end{array}$ & $0.05 * * *$ & $0.019 * *$ & $0.06^{* * *}$ & $0.05 * * *$ & $0.016^{* *}$ \\
\hline & $(0.0157)$ & $(0.0075)$ & $(0.0157)$ & $(0.008)$ & $(0.0157)$ & $(0.016)$ & $(0.008)$ & $(0.0157)$ & $(0.016)$ & $(0.0079)$ \\
\hline $\mathrm{I} * \mathrm{M}$ & & & & $\begin{array}{l}0.0006 \\
(0.0026)\end{array}$ & & & & & & \\
\hline $\mathrm{I} * \mathrm{CM}$ & & & & & & & & & & $\begin{array}{l}-0.00002 \\
(0.0021)\end{array}$ \\
\hline
\end{tabular}




\begin{tabular}{|c|c|c|c|c|c|c|c|c|c|c|}
\hline $\mathrm{I} * \mathrm{AM}$ & & & & & & & & & & $\begin{array}{l}0.001 \\
(0.0023)\end{array}$ \\
\hline $\mathrm{H} * \mathrm{I}$ & $\begin{array}{l}-0.01 * * * \\
(0.002)\end{array}$ & $\begin{array}{l}-0.001 \\
(0.001)\end{array}$ & $\begin{array}{l}-0.01 * * * \\
(0.002)\end{array}$ & $\begin{array}{l}-0.001 \\
(0.001)\end{array}$ & $\begin{array}{l}-0.01 * * * \\
(0.002)\end{array}$ & $\begin{array}{l}-0.01 * * * \\
(0.002)\end{array}$ & $\begin{array}{l}-0.0001 \\
(0.001)\end{array}$ & $\begin{array}{l}-0.01 * * * \\
(0.002)\end{array}$ & $\begin{array}{l}-0.01 * * * \\
(0.002)\end{array}$ & $\begin{array}{l}0.001 \\
(0.0009)\end{array}$ \\
\hline $\begin{array}{l}\text { Instruments } \\
\text { Controls }\end{array}$ & $\begin{array}{l}\text { Yes } \\
\text { Yes }\end{array}$ & $\begin{array}{l}\text { No } \\
\text { Yes }\end{array}$ & $\begin{array}{l}\text { Yes } \\
\text { Yes }\end{array}$ & $\begin{array}{l}\text { No } \\
\text { Yes }\end{array}$ & $\begin{array}{l}\text { Yes } \\
\text { Yes }\end{array}$ & $\begin{array}{l}\text { Yes } \\
\text { Yes }\end{array}$ & $\begin{array}{l}\text { No } \\
\text { Yes }\end{array}$ & $\begin{array}{l}\text { Yes } \\
\text { Yes }\end{array}$ & $\begin{array}{l}\text { Yes } \\
\text { Yes }\end{array}$ & $\begin{array}{l}\text { No } \\
\text { Yes }\end{array}$ \\
\hline $\begin{array}{l}\text { Rho M-job } \\
\text { search } \\
\text { Rho CM-job } \\
\text { search } \\
\text { Rho AM-job } \\
\text { search } \\
\text { Rho CM - AM }\end{array}$ & \multicolumn{2}{|l|}{$\begin{array}{l}0.126 * * \\
(0.0509)\end{array}$} & \multicolumn{2}{|c|}{$\begin{array}{l}0.126^{* *} \\
(0.0508)\end{array}$} & \multicolumn{3}{|c|}{$\begin{array}{l}-0.573 * * * \\
(0.145) \\
0.101 * * \\
(0.0423) \\
0.517 * * * \\
(0.0113)\end{array}$} & \multicolumn{3}{|l|}{$\begin{array}{l}-0.572 * * * \\
(0.144) \\
0.0959 * * \\
(0.0420) \\
0.517 * * * \\
(0.0113)\end{array}$} \\
\hline $\log \mathrm{L}$ & \multicolumn{2}{|l|}{-25952.95} & \multicolumn{2}{|l|}{-25951.13} & \multicolumn{3}{|l|}{-43295.65} & \multicolumn{3}{|l|}{-43283.11} \\
\hline Wald Chi 2 & \multicolumn{2}{|c|}{$7847.79 * * *$} & \multicolumn{2}{|c|}{7854.93 *** } & \multicolumn{3}{|c|}{$14339.11 * * *$} & \multicolumn{3}{|l|}{14268.83} \\
\hline Pseudo R2 & \multicolumn{2}{|c|}{0.12} & \multicolumn{2}{|l|}{0.12} & \multicolumn{3}{|c|}{0.09} & \multicolumn{3}{|l|}{\begin{tabular}{|l|}
0.09 \\
\end{tabular}} \\
\hline Observations & \multicolumn{2}{|l|}{14,248} & \multicolumn{2}{|l|}{14,248} & \multicolumn{3}{|l|}{14,248} & \multicolumn{3}{|l|}{14,248} \\
\hline
\end{tabular}

Notes: Each column of the table reports the key variables of interest in the model. The unreported results are available on request. Robust standard errors clustered at the level of working in the same organisation in parentheses. Weighted estimations. Columns (2), (4), (7) and (10) report average marginal effects; other columns report coefficients. Rho are correlations parameters between error terms of equations. * significant at $10 \%$; ** significant at $5 \%$; *** significant at $1 \%$. 
The relationships between the workplace environment and employees' motivations

The results are in line with the theoretical frameworks of mutual gains, social exchange theory, job demands-resources model, psychological contract and self-determination theory (Blau, 1964; Deci and Ryan, 1985; Osterman, 2000; Rousseau, 1995; Schaufeli and Bakker, 2004) as stated in Hypothesis 1, and empirical evidence summarized in Hypothesis 3. Employees indeed reciprocate to the organisational and technological workplace environment created by their employer by increasing their motivations. In detail, in Model 1, the reported results underline that both the HRM and the ICT bundles are positively related to the overall work motivation index, while the combined intensity of both bundles is negatively related. This result is consistent with the one of Martin (2017). It suggest that it is lightly detrimental to both participate in HRM practices and use ICT intensively. When the distinction between the controlled and the autonomous part of employees' motivations is made in Model 2, the same results are observed. HRM and ICT taken separated contribute to create a motivational environment but a high number of the two is lightly detrimental.

\section{The relationships between the workplace environment and on-the-job search behaviour}

The results are in line with Hypothesis $2 \mathrm{a}$ and permit to reveal a link between the ICT bundle and on-the-job search that is indeterminate in Hypothesis $2 b$. The results of Model 1 show indeed a direct negative relationship between the HRM bundle and on-the-job search and a positive relationship between the ICT bundle and on-the-job search. ${ }^{5}$ In Model 2, the distinction between controlled and autonomous motivations provides similar results. HRM investments support employers to retain employees in their current job. This result is in line with the

\footnotetext{
${ }^{5}$ Moreover, the results (reported in Appendix Table A7) confirm what previous papers have said on the positive relationships between adverse working conditions and employee on-the-job search especially when the two types of motivation are not disentangled. The foreign nationality of the employee when significantly related to turnover intention is negative, sustaining the fact that the current job is preferred to the job they can find elsewhere including their country of origin (especially French and Portuguese employees).
} 
empirical evidence underlining negative associations between some HRM practices and turnover intention (e.g. Cottini et al., 2011; Green et al., 2000).

Looking inside the practices that are the most covered in the highest score of the HRM bundle (see Appendix Table A2 for details), it is important that employees are encouraged to participate in workplace life (meeting, attitude surveys and quality circle), to take advantage of opportunities offered by employers for career development (such as training and formal appraisal), for work-life conciliation (such as flexible work time) and to obtain fringe benefits. ${ }^{6}$

Conversely, the increase in motivations linked to the ICT bundle may be outweighted by the positive link of the ICT bundle with on-the-job search. The work-family conflicts and/or stress that can be generated by an intensive use of all the ICT covered in the present analysis except Internet (e.g. Schieman and Young, 2013) seem to pushe employees to search for a new job.

This result on ICT is deepened by the results of other variables included in the model, and especially the matching quality variables about ICT skills (the results are reported in Appendix Table A7). They underline that being over-skilled in ICT increases the probability of searching for another job. This result reflects higher employment opportunities on the market of employees over-skilled in ICT related to the fact that high ICT skills are largely sought by employers in the current context of digitalization of jobs (Brynjolfsson and McAfee, 2016). On the contrary, and in line with the skill-biased technological changes literature (e.g. Chennels and Van Reenen, 2002), being under-skilled in ICT pushes employees towards the exit. The interaction term between between the HRM bundle and the ICT one is not significant.

The potential endogeneity of HRM (or ICT) in on-the-job search due to reverse causality is a standard issue for any analysis with such variables as independent variables and this analysis

\footnotetext{
${ }^{6}$ It should be noted that among the four fringe benefits covered in this study, the most diffused are meal vouchers and supplementary pension/life insurance.
} 
is not immune to this issue. Nevertheless as underlined by Batt et al. (2002) the negative effect of HRM on quit rate remains significant after taking into account the potential presence of reverse causality. Moreover, as stated by Cottini et al. (2011: page 877) "it is not obvious that [HRM practices (called HIWPs in their paper)] are adopted by those firms with already low employee turnover".

\section{The role of employees' motivations in on-the-job search behaviour}

The results related to the type of employees' motivation are in line with the self-determination theory (e.g. Gagné and Deci, 2005) as stated in Hypothesis 4a and Hypothesis 4b. They support the fact that the two types of motivations need to be disentangled as they have opposite relationships with on-the-job search. The present study that enlarges the spectrum of employees' motivations assessed in recent studies like those conducted by Kuvaas et al. (2017) shows that the highly motivated are less likely to search. When the two facets of work motivation are disentangled, the results presented in columns (7) and (10) stress that autonomously motivated employees are more likely to stay. On the contrary, employees motivated by reward and compulsion reasons, have a higher likelihood to search for another job. This result is in line with the ones of Kuvaas et al. (2017) and Vansteenkiste et al. (2007) that focuses on the link between extrinsic motivation (or extrinsic work-value orientation) and turnover intention.

Specifications 2 of the models that include interaction variables between the HRM bundle and motivation measures, underline interesting additional results. The results in column (4) emphasise that HRM practices reinforce the desire to stay with the employer of intensively motivated employees. The results in column (10) reveals that autonomously motivated employees are those that are more likely to stay in line with Hypothesis 5a. Furthermore, even 
if the HRM bundle increases controlled motivations, it appears that the HRM strategy has a turnover-increasing effect on those employees and it permits to reveal a link that is indeterminate in Hypothesis 5b. The organisational workplace environment does not seem to thwart the relationship, shown in the literature, between extrinsic motivation and continuance commitment (Gagné et al., 2010 and Kuvaas et al., 2017) to obtain a positive relationship with affective commitment that can retain those employees. Moreover, they can be attracted by external job opportunities and especially those with better wages as indirectly highlighted by the fact that the control variable 'better wages in the sector than in the firm' is positively related to on-the-job search (see Appendix Table A7).

Specifications 2 of the models that include interaction variables between the ICT bundle and motivations reveal that ICT interactions with motivation types do not provide significant results (columns (4) and (10)). This result suggests a neutral influence of motivation in the positive relationship between the ICT bundle and turnover intention of the employee (Hypothesis 5c).

A final comment is required about the issue of the potential self-selection into jobs of autonomously motivated employees based on the public available information on the management practices and technologies of the firm. They could attract autonomously motivated employees, strengthen their motivation and retain them. The available data do not permit to solve perfectly this issue, but as this effect goes in the same direction as the mechanism studied here this issue may not be fatally serious.

\section{Robustness checks $^{7}$}

To measure the impact of accounting for the potential endogeneity of motivations and the control for the unobserved heterogeneity across equations, the reduced-form of models presented in Table 2 are estimated. The main results about HRM, ICT bundles and on-the-job

\footnotetext{
${ }^{7}$ All of the results are available on request.
} 
search behaviour of motivated employees are not modified. Given the significant correlations in the error terms across equations are not zero, it is not surprising that single equation estimates of motivation(s) are smaller than those resulting from the results presented in Table 2 . The HRM bundle remains negative and statistically significant, the ICT bundle positive and significant. Autonomously motivated employees remain those that want to stay in their current job while controlled motivated employees want to quit their current job. The turnoverincreasing effect of HRM on controlled motivated employees and the turnover-reducing effect of HRM on autonomously motivated employees remain. Nevertheless, in this specification, the average marginal effect associated with controlled motivation disappears suggesting the need of taking into account the correlations between the two types of motivations to disentangle onthe-job search behaviour of those mainly motivated by internal reasons from those mainly motivated by external reasons.

In a second robustness check, the overall measure of job satisfaction instead of work motivation(s) is studied. As the overall job satisfaction measure is highly correlated with the autonomous motivation measure (correlation coefficient of 0.6155 and significant at the $1 \%$ level), it is not surprising to observe the same pattern of results between the participation in HRM and the use of ICT and the measure of autonomous motivation. Nevertheless, the average marginal effect of job satisfaction in on-the-job search equation is smaller than that of autonomous motivation shown in Table 2 .

In a third robustness check, other bundles are created to introduce only the core High Involvement Management (HIM) practices (participation, team work, training, incentive pay) as defined, for example by Kalmi and Kauhanen (2008), and the core ICT (Internet and email excluded) as defined by Bloom et al. (2014). The main results are not modified. 


\section{Conclusion}

Analysis of the on-the-job search behaviour of employees is important as employee turnover is costly for employers, especially if the motivated employees choose to quit their current job. Motivated employees, and especially the autonomously motivated ones who are, indeed, the ones assumed to provide the highest level of work effort, are a valuable resource for firms and need to be retained. In recent decades, the turnover intention of employees has gained the attention of human resource management, organisational psychology, labour, behavioural and personnel economic scholars. The main result underlined by the literature is that satisfied employees are those who have no intention of leaving their current employer. But being satisfied does not necessarily mean that the employee is motivated and exerts a high degree of effort. To motivate its workforce and retain the motivated employees, employers could invest in a motivational organisational environment but with what outcome?

This article adds to the literature on two major ways. First, while the working environment of employees has been captured by previous research mostly through adverse working conditions or at best a narrow range of management practices and of technologies, this paper analyses the role played by participation in the human resource management strategy of the employer and the use of technologies taking into account adverse working conditions and control for a large set of employee, job and current employer characteristics. Second, conversely to previous researches that mainly focus their attention on job satisfaction in the analyses of turnover intentions, I introduce the whole spectrum of work motivations which are the key drivers of employees productivity efforts. The insertion of the self-determination theory (Deci and Ryan, 1985; 2000; Gagné and Deci, 2005; Gagné et al., 2010) in labour market analysis provides new ways of characterizing employees: on the one hand, there are employees who exert effort because of autonomous motivation based on values, identification and intrinsic reasons, and, on the other hand, there are employees who exert effort because of controlled motivations based

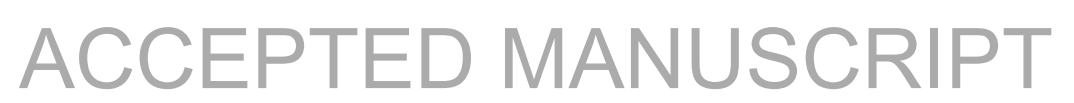


on rewards and out of feelings of compulsion. Autonomous motivation is a desired attribute of employees for managers as those employees exert positive behaviours at work (such as cooperation, information sharing, commitment and high intra and extra-role performance). Conversely, employees mainly driven by their controlled motivation are less sought by employers as they exert only one positive behaviour at work that is continuance commitment (i.e. staying in the current job to avoid the costs related to quit; Kuvaas et al., 2017).

I took advantage of a recent original survey collected in 2013 to analyse the relationships between the participation in HRM practices, ICT use, motivations and on-the-job search from employees working in the private sector of a Western European service economy, namely Luxembourg. The results do not concern only Luxembourgish employees but also employees from other European countries, and especially French, Belgian, German and Portuguese ones.

The main results of the paper provide, first, insight into how the participation of employees in the organisational and technological strategy of their firm enhances their work motivations. The HRM bundle and the ICT bundle are, indeed, positively related to all facets of work motivations. Second, the results support the use of motivations in the analysis of on-the-job search. Employees motivated by values, identification and intrinsic reasons are those that do not want to leave. Conversely, employees motivated by reward and feeling of obligation are those that want to quit in order to find a more suitable workplace elsewhere. The participation in HRM is negatively related to the on-the-job search of autonomously motivated employees and, conversely, is positively related to the exit intention of controlled motivated ones.

My findings also have practical managerial implications for employers. First, it is important that employers see autonomous and controlled motivations as separate motives. Second, employers should invest as far as they can in a positive organisational environment. The results posit that the participation in a bundle of HRM practices is fruitful for increasing the work 
motivations of employees. More specifically, a motivational work environment supposes the recourse to a bundle of management practices that covers information sharing and staff pulsetaking (through meetings, attitude surveys and quality circle), guiding employees in their job (via quality norm), career development activities (including encouraging staff development, trainings and formal appraisal), family-friendly policies (flexible work time and work-life balance consideration) and fringe benefits. Except trainings and fringe benefits, the other HRM practices covered in the highest level of the HRM bundle do not induce high cost to implement. Using technologies that decrease the access cost of information and the cost of communication participate together in the providing of a motivational environment. Nevertheless, this positive link can be outweighted by a positive association with on-the-job search. Employers should find a way to mitigate this positive link by improving their ICT practices. For example, employer should define a charter that requires managers and employees to disconnect from their job after working hours. It should reduce the perverse effect of ICT in terms of blurring of work-life boundaries and stress. Moreover, they should find a way to retain employees overskilled in ICT especially in the current context of the digitalization of jobs (Brynjolfsson and McAfee, 2016).

Moreover, knowledge about the type of employees that intend to leave can help employers to improve retention of highly motivated employees and reduce the costs associated with employee turnover. Autonomous motivation is a desired attribute for firms. Thus, it is reassuring for managers to know that autonomously motivated employees are the ones that want to stay in their current position. Furthermore, with the investments in their HRM strategy employers find a way to retain these employees. Conversely, employees who want to quit their current job are those motivated by external reasons: reward and/or compulsion. The leave of such employees if it happens will not induce high costs for employers as they have been shown in the literature to not perform above autonomously motivated employees except for simple

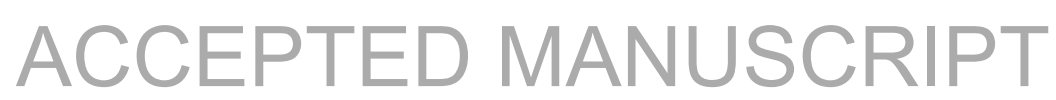


and easily measurable outcomes, are subject to negative emotions and stay in the current organisation mainly because of necessity. Moreover, the HRM strategy defined by managers has a turnover-increasing effect on these employees.

A potential shortcoming of this analysis is that the data set is cross-sectional. The fact that they could only be measured over one period of time, i.e. 2013, introduces some caution in the interpretation of the findings. Analyses that use panel data that permit to correct for unobservable time-invariant heterogeneity could further investigate the effect of HRM and ICT on work motivations and turnover intention of motivated employees. Another avenue for future research is to examine the complementarities between HRM practices, ICT uses and combination of the two, to promote motivational and productive personnel management in organisations.

\section{Acknowledgements}

This research is part of the TWAIN project supported by the National Research Fund, Luxembourg (contract FNR/C11/LM/1196209) and by core funding for LISER (formerly CEPS/INSTEAD) from the Ministry of Higher Education and Research of Luxembourg. I am grateful to Francis Green (LLAKES/University College London), Nicolas Poussing (LISER/CREM), Bertrand Verheyden (LISER) and Mathias Kuepie (LISER) for their valuable comments on previous versions of the paper. I thank the National Ministry of Social Security of Luxembourg and LISER for sponsoring and giving the access to the 'Survey on working conditions and quality of work life'.

\section{References}

Akerlof GA and Kranton RE (2005) Identity and the economics of organizations. The Journal of Economic Perspectives 19(1): 9-32. 
Akerlof GA, Rose AK, Yellen JL, Ball L, and Hall R E (1988) Job switching and job satisfaction in the U.S. labor market. Brookings Papers on Economic Activity 1988(2): 495594.

Antecol H, and Cobb-Clark D (2009) Racial harassment, job satisfaction, and intentions to remain in the military. Journal of Population Economics 22(3): 713-738.

Antecol H, Barcu, VE, and Cobb-Clark D (2009) Gender-biased behavior at work: Exploring the relationship between sexual harassment and sex discrimination. Journal of Economic Psychology 30(5): 782-792.

Askenazy P, Thesmar D, and Thoenig M (2006) On the relation between organizational practices and new technologies: the role of (time based) competition. The Economic Journal 116(508): 128-154.

Baard PP (2004) Intrinsic need satisfaction in organizations: a motivational basis of success in for-profit and not-for-profit settings, in Deci EL and Ryan MR (eds), Handbook of Selfdetermination Research. Rochester: University of Rochester, pp. 255-73.

Bareket-Bojmel L, Hochman G and Ariely D (2014). It's (not) all about the Jacksons: Testing different types of short-term bonuses in the field. Journal of Management 43(2): 534-554.

Batt R (2004) Who benefits from teams? Comparing the outcomes for managers, supervisors, and workers. Industrial Relations 43(1): 183-213.

Batt R, Colvin AJS and Keefe J (2002) Employee voice, human resource practices, and quit rates: Evidence from the telecommunications industry. Industrial and Labor Relations Review 55(4): 573-594.

Bauer T K (2004) High performance workplace practices and job satisfaction: Evidence from Europe. Discussion Papers Series IZA DP No. 1265, Institute for the Study of Labor.

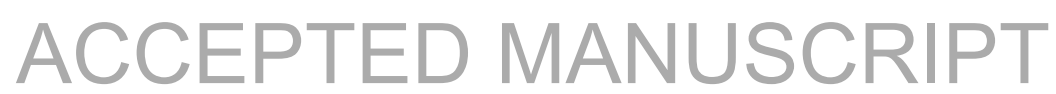


Bauer T K and Bender S (2004) Technological change, organizational change, and job turnover. Labour Economics 11(3): 265-291.

Baum CF, Schaffer ME and Stillman S (2007) Enhanced routines for instrumental variables / generalized method of moment estimation and testing. The Stata Journal 7(4): 465-506.

Blau, P. (1964) Exchange and Power in Social Life, New York: Wiley.

Bloom N, Garicano L, Sadun R, and Van Reenen J (2014) The distinct effects of information technology and communication technology on firm organization. Management Science 60(12): $2859-2885$.

Bloom N, Sadun R and Van Reenen J (2012) Americans do IT better: US multinational and the productivity miracle. The American Economic Review 102(1): 167-201.

Böckerman P and Ilmakunnas P (2009) Job disamenities, job satisfaction, quit intentions, and actual separations: Putting the pieces together. Industrial Relations 48(1): 73-96.

Böckerman P, Ilmakunnas P, Jokisaari M and Vuori J (2013) Who stays unwillingly in a job? A study based on a representative random sample of employees. Economic and Industrial Democracy 34(1): 25-41.

Böckerman P, Bryson A and Ilmakunnas P (2012) Does high involvement management improve worker wellbeing? Journal of Economic Behavior \& Organization 84(2): 660-680.

Bowen DE and Ostroff C (2004) Understanding HRM-performance linkages: The role of the strength of the HRM system. Academy of Management Review 29(2): 203-221.

Boxall P (2013) Mutuality in the management of human resources: assessing the quality of alignment in employment relationships. Human Resource Management Journal 23(1): 3-17. 
Boxall P and Macky K (2009) Research and theory on high-performance work systems: progressing the high-involvement stream. Human Resource Management Journal 19(1): 3-23.

Bresnahan TF, Brynjolfsson E and Hitt LM (2002) Information technology, workplace organization, and the demand for skilled labor: Firm-level evidence. The Quarterly Journal of Economics 117(1): 339-376.

Brown A, Forde C, Spencer D and Charlwood A (2008) Changes in HRM and job satisfaction, 1998-2004: evidence from the Workplace Employment Relations Survey. Human Resource Management Journal 18(3): 237-256.

Brynjolfsson E and Hitt LM (2000) Beyond computation: Information technology, organizational transformation and business performance. The Journal of Economic Perspectives 14(4): 23-48.

Brynjolfsson E and McAfee A (2016) The second machine age: Work, progress, and prosperity in a time of brilliant technologies. New York: W. W. Norton \& Company.

Caroli E and Van Reenen J (2001) Skill-biased organizational change? Evidence from a panel of British and French establishments. The Quarterly Journal of Economics 116(4): 1449-1492.

Chennels L and Van Reenen J (2002) Technical change and the structure of employment and wages: a survey of microeconometric evidence. In: Greenan N, L’Horty Y and Mairesse J (eds) Productivity, Inequality and the Digital Economy. A Transatlantic Perspective. Cambridge, MA: MIT Press, chapter 5, pp.175-223.

Clark AE (2001) What really matters in a job? hedonic measurement using quit data. Labour Economics 8(2): 223-242.

Clark AE and Oswald A (1996) Satisfaction and comparison income. Journal of Public Economics 61(3): 359-381.

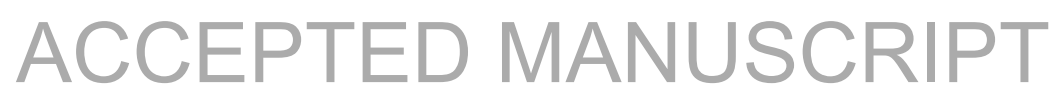


Clark AE, Georgellis Y and Sanfey P (1998) Job satisfaction, wage changes, and quits: Evidence from Germany. Research in Labor Economics 17: 95-121.

Combs J, Yongmei L, Hall A and Ketchen D (2006) How much do high-performance work practices matter? A meta-analysis of their effects on organizational performance. Personnel Psychology 59(3): 501-528.

Cottini E, Kato T and Westergaard-Nielsen N (2011) Adverse workplace conditions, highinvolvement work practices and labor turnover: Evidence from Danish linked employeremployee data. Labour Economics 18(6): 872-880.

Deci EL and Ryan RM (1985) Intrinsic motivation and self-determination in human behaviour. New York, NY: Plenum.

Deci EL and Ryan RM (2000) The "What" and "Why" of goal pursuits: Human needs and the self-determination of behavior. Psychological Inquiry 11(4): 227-268.

Delfgaauw J (2007) The effect of job satisfaction on job search: Not just whether, but also where. Labour Economics 14(3): 299-317.

Dessein W and Santos T (2006) Adaptive organizations. Journal of Political Economy 114(5): 956-995.

Dysvik A and Kuvaas B (2008) The relationship between perceived training opportunities, work motivation and employee outcomes. International Journal of Training and Development 12(3): $138-157$.

Dysvik A and Kuvaas B (2010) Exploring the relative and combined influence of masteryapproach goals and work intrinsic motivation on employee turnover intention. Personnel Review 36(5): 622-638. 
Eriksson T and Kristensen N (2014) Wages or fringes? Some evidence on trade-offs and sorting. Journal of Labor Economics 32(4): 899-928.

Ernst Kossek E and Ozeki C (1998) Work-family conflict, policies, and the job-life satisfaction relationship: a review and directions for organizational behavior human resources research. Journal of Applied Psychology 83(2): 139-149.

Fehr E, Gächter S and Kirchsteiger G (1997) Reciprocity as a contract enforcement device: Experimental evidence. Econometrica 65(4): 833-860.

Fenner GH and Renn RW (2010) Technology-assisted supplemental work and work-to-family conflict: The role of instrumentality beliefs, organizational expectations and time management. Human Relations 63(1): 63-82.

Freeman RB (1978) Job satisfaction as an economic variable. The American Economic Review 68(2): 135-141.

Gagné M and Deci EL (2005) Self-determination theory and work motivation. Journal of Organizational Behavior 26(4): 331-362.

Gagné M, Forest J, Gilbert MH, Aubé C, Morin E and Malorni A (2010) The motivation at work scale: validation evidence in two languages. Educational and Psychological Measurement 70(4): 628-646.

Gallie D, Felstead A, and Green F (2001) Employer policies and organizational commitment in Britain 1992-97. Journal of Management Studies 38(8): 1081-1101.

Gallie D, Zhou Y, Felstead A and Green F (2012) Teamwork, skill development and employee welfare. British Journal of Industrial Relations 50(1): 23-46.

Garcia-Serrano C (2004) Temporary employment, working conditions and expected exits from firms. Labour 18(2): 293-316.

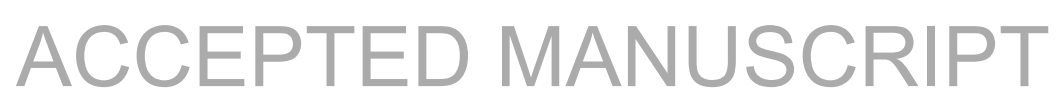


Godard J (2001) High performance and the transformation of work? The implications of alternative work practices for the experience and outcomes of work. Industrial and Labor Relations Review 54(4): 776-805.

Godard J (2004) A critical assessment of the high-performance paradigm. British Journal of Industrial Relations 42(2): 349-378.

Gómez-Miñambres J (2012) Motivation through goal setting. Journal of Economic Psychology 33(6): 1223-1239.

Gould-Williams J (2007) HR practices, organizational climate and employee outcomes: evaluation social exchange relationships in local government. International Journal of Human Resource Management 18(9): 1627-1247.

Green F (2010) Well-being, job satisfaction and labour mobility. Labour Economics 17(6): 897-903.

Green F, Felstead A, Mayhew K and Pack A (2000) The impact of training on labour mobility: Individual and firm-level evidence from Britain. British Journal of Industrial Relations 38(2): $261-275$.

Griffeth RW, Hom PW and Gaertner S (2000) A meta-analysis of antecedents and correlates of employee turnover: Update, moderator tests, and research implications for the next millennium. Journal of Management 26(3): 463-488.

Guest DE (1999) Human resource management - The workers verdict. Human Resource Management Journal 9(3): 5-25.

Haines VY, Jalette P and Larose K (2010) The influence of human resource management practices on employee voluntary turnover rates in the Canadian non governmental sector. Industrial and Labor Relations Review 63(2): 228-246.

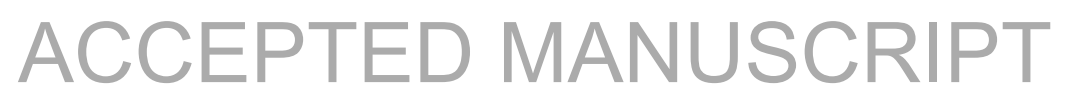


Hair JE, Anderson RE, Tatham RL and Black, WC (2006). Multivariate data analysis, 5th Ed. Englewood Cliffs, NJ: Pearson Prentice Hall.

Huselid MA (1995) The impact of human resource management practices on turnover, productivity, and corporate financial performance. The Academy of Management Journal 38(3): 635-672.

Ichniowski C, Kochan TA, Levine D, Olson C, and Strauss G (1996) What works at work: Overview and assessment. Industrial Relations 35(3): 299-333.

Ichniowski C and Shaw K (2013) Insider econometrics: Empirical studies of how management matters. In: Gibbons R and Roberts J (eds) Handbook of Organizational Economics. Princeton, NJ: Princeton University Press, chapter 7, pp.263-311.

Ichniowski C, Shaw K and Prennushi G (1997) The effects of human resource management practices on productivity: A study of steel finishing lines. The American Economic Review 87(3): 291-313.

Jones GR and Wright PM (1992) An economic approach to conceptualizing the utility of human resource management practices. In: Rowland K and Ferri G (eds) Research in personnel and human resources management. Greenwich, CT: JAI Press, Vol. 10, pp.271-299.

Kalmi P and Kauhanen A (2008) Workplace innovations and employee outcomes: Evidence from Finland. Industrial Relations 47(3): 430-459.

Karasek RA and Theorell T (1990) Healthy work Stress, productivity, and the reconstruction of working life. New York: Basic Book.

Kristensen N and Westergaard-Nielsen N (2006) Job satisfaction and quits - which job characteristics matters most? Danish Economic Journal 144(2): 230-249. 
Kuvaas B, Buch R, Weibel A, Dysvik A and Nerstad CGL (2017) Do intrinsic and extrinsic motivation relate differently to employee outcomes? Journal of Economic Psychology 61:244258.

Lévy-Garboua L, Montmarquette C and Simonnet V (2007) Job satisfaction and quits. Labour Economics 14(2): 251-268.

Lemyre PN, Roberts GC and Stray-Gundersen J (2007) Motivation, overtraining, and burnout: Can self-determined motivation predict overtraining and burnout in elite athletes? European Journal of Sport Science 7(2): 115-126.

MacDuffie JP (1995) Human resource bundles and manufacturing performance: Organizational logic and flexible production systems in the world auto industry. Industrial and Labor Relations Review 48(2): 197-221.

Macky K and Boxall P (2007) The relationship between high-performance work practices and employee attitudes: an investigation of additive and interaction effects. International Journal of Human Resource Management 18(4): 537-567.

Marescaux E, De Winne S and Sels L (2013) HR practices and HRM outcomes: the role of basic need satisfaction. Personnel Review 42(1): 4-27.Mark G, Iqbal ST, Czerwinski M, Johns P, Sano A (2016) Email duration, batching and self-interruption: Patterns of email use on productivity and stress. Proceedings of the 2016 CHI Conference on Human Factors in Computing Systems: 1717-1728

Martin L (2017) Do innovative work practices and ICT use motivate employees? Industrial Relations, 56(2): 263-292.

Martin L and Omrani N (2015) An assessment of trends in technology use, innovative work practices and employees attitudes in Europe. Applied Economics 47(6): 623-638.

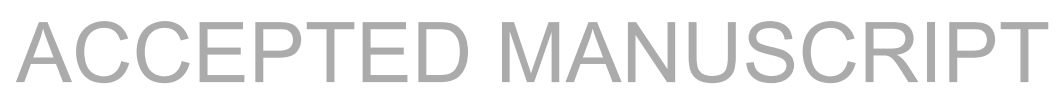


McGovern P, Hill S, Mills C and White M (2007) Market, class, and employment. Oxford: Oxford University Press.

MEADOW Consortium (2010) The MEADOW Guidelines. Project funded within the $6^{\text {th }}$ Framework Programme of the European Commission's DG Research. Grigny, France.

Meyer J, Stanley D, Herscovitch L and Topolnytsky L (2002) Affective, continuance, and normative commitment to the organization: a meta-analysis of antecedents, and consequences. Journal of Vocational Behavior 61(1): 20-52.

Milgrom P and Roberts J (1990) The economics of modern manufacturing: Technology, strategy, and organization. The American Economic Review 80(3): 511-528.

Minkler L (2004) Shirking and motivations in firms: Survey evidence on workers attitudes. International Journal of Industrial Organization 22(6): 863-884.

Mohr RD and Zoghi C (2008) High-involvement work design and job satisfaction. Industrial and Labor Relations Review 61(3): 275-296.

Morrow P and McElroy $\mathrm{J}$ (2007) Efficiency as a mediator in turnover-organizational performance relations. Human Relations 60(6): 827-849.

Mowday RT, Porter LW and Steers RM (1982) Employee-organization linkages: The psychology of commitment, absenteeism, and turnover. New York: Academic Press.

Oi W (1962) Labor as a quasi-fixed factor. Journal of Political Economy 70(6): 538-555.

Osterman P (2000) Work reorganization in an era of restructuring: Trends in diffusion and effects on employee welfare. Industrial and Labor Relations Review 53(2): 179-196.

Pissarides CA and Wadsworth J (1994) On-the-job search: Some empirical evidence from Britain. European Economic Review 38(2): 213-415. 
Ramsay H, Scholarios D and Harley B (2000) Employees and high-performance work systems: Testing inside the black box. British Journal of Industrial Relations 38(4): 501-531.

Roodman D (2011) Fitting fully observed recursive mixed-process models with CMP. Stata Journal 11(2): 159-206.

Rousseau D (1990) New hire perceptions of their own and employer's obligations: A study of psychological contracts. Journal of Organizational Behavior 11: 389-400.

Rousseau D (1995) Psychological contracts in organisations: Understanding the written and unwritten agreements. London: Sage.

Schaufeli W B and Bakker A. B. (2004) Job demands, job resources, and their relationship with burnout and engagement: a multi-sample study. Journal of Organizational Behavior 25(3): $293-315$.

Schieman S and Young MC (2013) Are communications about work outside regular working hours associated with work-to-family conflict, psychological distress and sleep problems? Work \& Stress 27(3): 244-261.

Scott A, Gravelle H, Simoens S, Bojke C and Sibbald B (2006) Job satisfaction and quitting intentions: A structural model of British general practitioners. British Journal of Industrial Relations 44(3): 519-540.

Shields MA and Wheatley Price S (2002) Racial harassment, job satisfaction and intentions to quit: Evidence from the British nursing profession. Economica 69(274): 295-326.

Sousa-Poza A and Henneberg F (2004) Analysing job mobility with job turnover intentions: An international comparative study. Journal of Economic Issues 38(1): 113-137.

Staiger D and Stock JH (1997) Instrumental variables regression with weak instruments. Econometrica 65(3): 557-586.

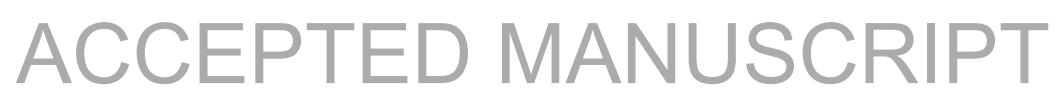


Sturges J, Conway N, Guest D and Liefooghe A (2005) Managing the career deal: The psychological contract as a framework for understanding career management, organizational commitment and work behaviour. Journal of Organizational Behavior 26, 821-838.

Suazo M M, Martínez P G and Sandoval R (2009) Creating psychological and legal contracts through human resource practices: A signaling theory perspective. Human Resource Management Review 19(2): 154-166.

Theodossiou I and Zangelidis A (2009) Should I stay or should I go? The effect of gender, education and unemployment on labour market transitions. Labour Economics 16(5): 566-577.

Van Ophem H (1991) Wages, nonwage job characteristics and the search behavior of employees. The Review of Economics and Statistics 73(1): 145-151.

Vansteenkiste M, Neyrinck B, Niemiec CP, Soenens B, De Witte H and Van den Broeck A (2007) On the relations among work value orientations, psychological need satisfaction and job outcomes: A self-determination theory approach. Journal of Occupational and Organizational Psychology 80: 251-277.

Weibel A, Rost K and Osterloh M (2010) Pay for performance in the public sector: Benefits and (hidden) costs. Journal of Public Administration Research and Theory 20(2): 387-412.

White M and Bryson A (2013) Positive employee attitudes: How much human resource management do you need? Human Relations 66(3): 385-406.

Wood S (1999) Human Resource Management and Performance. International Journal of Management Review 1(4): 367-413.

Wu N, Hoque K, Bacon N and Bou Llusar JC (2015) High-performance work systems and workplace performance in small, medium-sized and large firms. Human Resource Management Journal 25(4): 408-423.

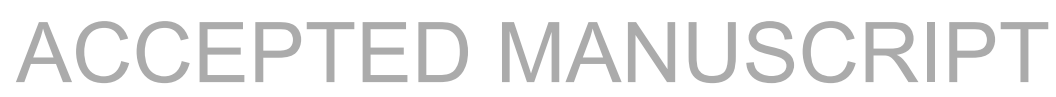




\section{Appendix}

Table A1. Descriptive statistics on the management practices introduced in the HRM and HIM bundle (in \%).

\begin{tabular}{|c|c|c|c|c|}
\hline $\begin{array}{l}\text { Domain name and } \\
\text { content }\end{array}$ & Measurement & Mean & $H R M$ & $H I M$ \\
\hline \multicolumn{5}{|l|}{ Participation } \\
\hline $\begin{array}{l}\text { Meeting between } \\
\text { management and } \\
\text { the staff }\end{array}$ & $\begin{array}{l}\text { As regards information and communication within your } \\
\text { company, how do you rate the usefulness of meeting(s) } \\
\text { between employees and management? Very useful or } \\
\text { Moderately useful = } 1 \text {; not useful or does not exist }=0\end{array}$ & 65.83 & Yes & Yes \\
\hline $\begin{array}{l}\text { Changes with } \\
\text { employees } \\
\text { involved }\end{array}$ & $\begin{array}{l}\text { Do you participate in decisions concerning major } \\
\text { changes within your company? Yes }=1 ; \text { No }=0\end{array}$ & 12.77 & Yes & No \\
\hline Attitude surveys & $\begin{array}{l}\text { As regards information and communication within your } \\
\text { company, how do you rate the usefulness of Internal } \\
\text { survey(s) organised by the management? Very useful or } \\
\text { Moderately useful = } 1 \text {; Not useful or Does not exist }=0\end{array}$ & 41.12 & Yes & Yes \\
\hline Quality circle & $\begin{array}{l}\text { Are you involved in a group which meets regularly to } \\
\text { identify and resolve problems related to its work? } \\
\text { (quality groups or quality circles) Yes }=1 ; \text { No }=0\end{array}$ & 23.85 & Yes & No \\
\hline \multicolumn{5}{|l|}{ Team working } \\
\hline $\begin{array}{l}\text { Autonomous team } \\
\text { work }\end{array}$ & $\begin{array}{l}\text { Based on two survey questions: the employee works in a } \\
\text { team of at least } 3 \text { individuals with the control of work } \\
\text { quality done by team members }=1 \text {; otherwise }=0\end{array}$ & 30.91 & Yes & Yes \\
\hline Job rotation & $\begin{array}{l}\text { When you are absent for one week, what proportion of } \\
\text { your tasks must you catch up on when you return? } \\
\text { Nothing or just a small proportion; Less than half }=1 \text {; } \\
\text { More than half or Almost all my work }=0\end{array}$ & 52.15 & Yes & No \\
\hline Quality norms & $\begin{array}{l}\text { Do you must comply with quality standards (ISO } \\
\text { standards, } \ldots)=1 ; \text { otherwise }=0\end{array}$ & 58.85 & Yes & No \\
\hline \multicolumn{5}{|l|}{ Development } \\
\hline $\begin{array}{l}\text { Development } \\
\text { policy }\end{array}$ & $\begin{array}{l}\text { Do you agree or disagree with the following statement: } \\
\text { My company encourages its staff to develop their } \\
\text { competences and their careers? Agree or Strongly agree } \\
=1 ; \text { Strongly disagree or Disagree }=0\end{array}$ & 53.01 & Yes & No \\
\hline Training & $\begin{array}{l}\text { In the last } 12 \text { months, have you attend training related to } \\
\text { your work paid by your company? Yes }=1 ; \mathrm{No}=0\end{array}$ & 41.60 & Yes & Yes \\
\hline Formal appraisal & $\begin{array}{l}\text { In the last } 12 \text { months, did you have at least one appraisal } \\
\text { interview? Yes }=1 ; \text { No }=0\end{array}$ & 57.76 & Yes & No \\
\hline \multicolumn{5}{|l|}{$\begin{array}{l}\text { Family-friendly } \\
\text { policies }\end{array}$} \\
\hline $\begin{array}{l}\text { Flexible work } \\
\text { time }\end{array}$ & $\begin{array}{l}\text { Do you have flexible working hours (you decide } \\
\text { yourself when you start and stop work, taking into } \\
\text { account certain daily fixed time slots)? Yes }=1 ; \text { No }=0\end{array}$ & 38.24 & Yes & No \\
\hline Work-life balance & $\begin{array}{l}\text { Do you agree or disagree with the following statement: } \\
\text { My company implements policies which permit a good } \\
\text { work-life balance? Agree or Strongly agree }=1 ; \\
\text { Strongly disagree or Disagree }=0\end{array}$ & 38.14 & Yes & No \\
\hline $\begin{array}{l}\text { Working at home } \\
\text { in work hours }\end{array}$ & $\begin{array}{l}\text { Does your company permit you to do working at (or } \\
\text { from) home in normal working hours? If yes, do you } \\
\text { make use of this possibility? Sometimes or often = } 1 \text {; } \\
\text { Never }=0\end{array}$ & 7.63 & Yes & No \\
\hline
\end{tabular}




\begin{tabular}{|c|c|c|c|c|}
\hline \multicolumn{5}{|l|}{ Incentives } \\
\hline Incentive pay & $\begin{array}{l}\text { Do you have a fixed or variable salary (depending on } \\
\text { productivity ...)? Variable or Fixed + a variable element } \\
=1 \text {; Fixed }=0\end{array}$ & 33.14 & Yes & Yes \\
\hline Fringe benefits & $\begin{array}{l}\text { Do the following fringe benefits are offered to you? At } \\
\text { least one of the following: company car or car fee } \\
\text { participation; supplementary pension or life insurance; } \\
\text { meal vouchers = 1; otherwise = } 0\end{array}$ & 49.47 & Yes & No \\
\hline \multirow{11}{*}{ HRM bundle } & 0 or 1 & 3.38 & & \\
\hline & 2 & 5.94 & & \\
\hline & 3 & 9.75 & & \\
\hline & 4 & 10.95 & & \\
\hline & 5 & 13.1 & & \\
\hline & 6 & 14.05 & & \\
\hline & 7 & 12.43 & & \\
\hline & 8 & 11.52 & & \\
\hline & 9 & 8.26 & & \\
\hline & 10 & 5.76 & & \\
\hline & 11 or more & 4.86 & & \\
\hline \multirow{5}{*}{ HIM bundle } & 0 & 11.22 & & \\
\hline & 1 & 21.53 & & \\
\hline & 2 & 27.71 & & \\
\hline & 3 & 24.96 & & \\
\hline & 4 or 5 & 14.58 & & \\
\hline Observations & & 14,248 & & \\
\hline
\end{tabular}

Notes: Weighted statistics. All management practices included in the HRM and HIM bundles are binary variables.

Table A2. Descriptive statistics on the percentage of employees concerned by each management practices according to the HRM bundle level (in \%).

\begin{tabular}{c|cccc|ccc}
\hline & \multicolumn{5}{|c|}{ Participation } & \multicolumn{3}{c}{ Team working } \\
\hline $\begin{array}{c}\text { HRM } \\
\text { bundle }\end{array}$ & $\begin{array}{c}\text { Meeting } \\
\text { between } \\
\text { manage- } \\
\text { ment and } \\
\text { the staff }\end{array}$ & $\begin{array}{c}\text { Changes } \\
\text { with } \\
\text { employees } \\
\text { involved }\end{array}$ & $\begin{array}{c}\text { Atti- } \\
\text { tude } \\
\text { surveys }\end{array}$ & $\begin{array}{c}\text { Quality } \\
\text { circle }\end{array}$ & $\begin{array}{c}\text { Autono- } \\
\text { mous } \\
\text { team work }\end{array}$ & $\begin{array}{c}\text { Job } \\
\text { rotation }\end{array}$ & $\begin{array}{c}\text { Quality } \\
\text { norms }\end{array}$ \\
\hline & Mean & Mean & Mean & Mean & Mean & Mean & Mean \\
\hline 0 or 1 & 0.07 & 0.00 & 0.01 & 0.00 & 0.04 & $\mathbf{0 . 2 9}$ & 0.18 \\
2 & 0.17 & 0.01 & 0.05 & 0.02 & 0.12 & $\mathbf{0 . 5 3}$ & $\mathbf{0 . 3 7}$ \\
3 & $\mathbf{0 . 3 0}$ & 0.03 & 0.11 & 0.05 & 0.17 & $\mathbf{0 . 5 6}$ & $\mathbf{0 . 5 1}$ \\
4 & $\mathbf{0 . 4 7}$ & 0.03 & 0.19 & 0.09 & 0.25 & $\mathbf{0 . 5 7}$ & $\mathbf{0 . 5 6}$ \\
5 & $\mathbf{0 . 6 0}$ & 0.06 & 0.29 & 0.13 & 0.27 & $\mathbf{0 . 5 6}$ & $\mathbf{0 . 5 8}$ \\
6 & $\mathbf{0 . 7 1}$ & 0.08 & 0.38 & 0.19 & 0.31 & $\mathbf{0 . 5 3}$ & $\mathbf{0 . 6 0}$ \\
7 & $\mathbf{0 . 8 3}$ & 0.12 & $\mathbf{0 . 5 2}$ & 0.26 & 0.36 & $\mathbf{0 . 5 1}$ & $\mathbf{0 . 6 3}$ \\
8 & $\mathbf{0 . 8 9}$ & 0.17 & $\mathbf{0 . 6 2}$ & 0.36 & 0.38 & 0.50 & $\mathbf{0 . 6 4}$ \\
9 & $\mathbf{0 . 9 4}$ & 0.23 & $\mathbf{0 . 7 1}$ & 0.43 & 0.43 & 0.48 & $\mathbf{0 . 6 7}$ \\
10 & $\mathbf{0 . 9 6}$ & 0.34 & $\mathbf{0 . 8 1}$ & $\mathbf{0 . 5 5}$ & 0.48 & 0.51 & $\mathbf{0 . 7 3}$ \\
11 or & $\mathbf{0 . 9 8}$ & 0.59 & $\mathbf{0 . 8 9}$ & $\mathbf{0 . 7 9}$ & 0.53 & 0.51 & $\mathbf{0 . 8 1}$ \\
\hline \multicolumn{7}{c}{ Development } & \multicolumn{7}{c}{ Family-friendly policies } & Incentives \\
\hline
\end{tabular}




\begin{tabular}{|c|c|c|c|c|c|c|c|c|}
\hline $\begin{array}{c}\text { HRM } \\
\text { bundle }\end{array}$ & $\begin{array}{l}\text { Develop- } \\
\text { ment } \\
\text { policy }\end{array}$ & Training & $\begin{array}{c}\text { Formal } \\
\text { apprai- } \\
\text { sal }\end{array}$ & $\begin{array}{c}\text { Flexible } \\
\text { work time }\end{array}$ & $\begin{array}{l}\text { Work-life } \\
\text { balance }\end{array}$ & $\begin{array}{c}\text { Working } \\
\text { at home in } \\
\text { work } \\
\text { hours }\end{array}$ & $\begin{array}{c}\text { Incentive } \\
\text { pay }\end{array}$ & $\begin{array}{l}\text { Fringe } \\
\text { benefits }\end{array}$ \\
\hline & Mean & Mean & Mean & Mean & Mean & Mean & Mean & Mean \\
\hline 0 or 1 & 0.02 & 0.04 & 0.03 & 0.02 & 0.02 & 0.00 & 0.06 & 0.05 \\
\hline 2 & 0.08 & 0.06 & 0.12 & 0.10 & 0.06 & 0.01 & 0.17 & 0.13 \\
\hline 3 & 0.17 & 0.13 & 0.23 & 0.15 & 0.16 & 0.02 & 0.23 & 0.21 \\
\hline 4 & 0.25 & 0.19 & 0.38 & 0.22 & 0.18 & 0.02 & 0.28 & 0.32 \\
\hline 5 & 0.38 & 0.31 & 0.48 & 0.30 & 0.27 & 0.04 & 0.32 & 0.41 \\
\hline 6 & 0.55 & 0.41 & 0.63 & 0.37 & 0.36 & 0.05 & 0.32 & 0.51 \\
\hline 7 & 0.68 & 0.49 & 0.74 & 0.44 & 0.41 & 0.07 & 0.36 & 0.58 \\
\hline 8 & 0.81 & 0.60 & 0.81 & 0.52 & 0.56 & 0.09 & 0.36 & 0.69 \\
\hline 9 & 0.89 & 0.73 & 0.87 & 0.63 & 0.66 & 0.14 & 0.43 & 0.76 \\
\hline 10 & 0.94 & 0.81 & 0.90 & 0.67 & 0.76 & 0.22 & 0.49 & 0.82 \\
\hline $\begin{array}{l}11 \text { or } \\
\text { more }\end{array}$ & 0.98 & 0.90 & 0.95 & 0.82 & 0.87 & 0.32 & 0.62 & 0.91 \\
\hline
\end{tabular}

Notes: Weighted statistics.

Table A3. Descriptive statistics on the ICT introduced in the ICT bundles (in \%).

\begin{tabular}{|c|c|c|c|c|}
\hline Content & Measurement & Mean & ICT & $I C T 2$ \\
\hline ERP & $\begin{array}{l}\text { Do you use Enterprise Resources Planning (a tool for } \\
\text { coordinating employees around the information system)? } \\
\text { Yes }=1 ; \text { No }=0\end{array}$ & 14.80 & Yes & Yes \\
\hline Workflow & $\begin{array}{l}\text { Do you use a Workflow (a tool for coordinating } \\
\text { employees around a business process)? Yes }=1 ; \text { No }=0\end{array}$ & 15.11 & Yes & Yes \\
\hline Groupware & $\begin{array}{l}\text { Do you use a Groupware (an information exchange } \\
\text { tool)? Yes }=1 ; \text { No }=0\end{array}$ & 24.37 & Yes & Yes \\
\hline Intranet & Do you use an Intranet? Yes $=1 ;$ No $=0$ & 50.18 & Yes & Yes \\
\hline Internet use & $\begin{array}{l}\text { Do you use Internet for work purposes at least } 25 \text { you're } \\
\text { your working time? Yes }=1 ; \text { No }=0\end{array}$ & 0.17 & Yes & No \\
\hline Email use & Do you use email for work purposes? Yes $=1 ;$ No $=0$ & 0.55 & Yes & No \\
\hline \multicolumn{5}{|l|}{ ICT bundle } \\
\hline 0 & & 38.12 & & \\
\hline 1 & & 8.79 & & \\
\hline 2 & & 17.65 & & \\
\hline 3 & & 17.24 & & \\
\hline 4 & & 11.40 & & \\
\hline 5 or 6 & & 6.79 & & \\
\hline \multicolumn{5}{|l|}{ ICT 2 bundle } \\
\hline 0 & & 44.37 & & \\
\hline 1 & & 23.94 & & \\
\hline 2 & & 18.29 & & \\
\hline 3 or 4 & & 13.4 & & \\
\hline Observations & & 14,248 & & \\
\hline
\end{tabular}

Notes: Weighted statistics. All ICT uses are binary variables.

Table A4. Descriptive statistics on the percentage of employees concerned by each ICT according to the ICT bundle level (in \%).

\begin{tabular}{ccccccc}
\hline ICT bundle & ERP & Workflow & Groupware & Intranet & Internet use & Email use \\
\hline & Mean & Mean & Mean & Mean & Mean & Mean \\
\hline
\end{tabular}




\begin{tabular}{ccccccc}
\hline 0 & 0.00 & 0.00 & 0.00 & 0.00 & 0.00 & 0.00 \\
1 & 0.05 & 0.02 & 0.05 & 0.36 & 0.03 & $\mathbf{0 . 4 9}$ \\
2 & 0.07 & 0.03 & 0.11 & $\mathbf{0 . 7 7}$ & 0.12 & $\mathbf{0 . 8 9}$ \\
3 & 0.20 & 0.18 & $\mathbf{0 . 4 3}$ & $\mathbf{0 . 9 1}$ & 0.32 & $\mathbf{0 . 9 7}$ \\
4 & 0.40 & $\mathbf{0 . 4 8}$ & $\mathbf{0 . 7 2}$ & $\mathbf{0 . 9 6}$ & 0.46 & $\mathbf{0 . 9 8}$ \\
5 or 6 & $\mathbf{0 . 7 5}$ & $\mathbf{0 . 8 6}$ & $\mathbf{0 . 9 3}$ & $\mathbf{0 . 9 9}$ & 0.65 & $\mathbf{1 . 0 0}$ \\
\hline
\end{tabular}

Notes: Weighted statistics.

Table A5. Descriptive statistics of control variables.

\begin{tabular}{|c|c|c|c|c|c|c|c|}
\hline \multicolumn{2}{|c|}{ Individual characteristics } & \multicolumn{2}{|l|}{ Job characteristics } & \multicolumn{2}{|l|}{$\begin{array}{l}\text { Organisation } \\
\text { characteristics }\end{array}$} & \multicolumn{2}{|c|}{ Outside opportunities } \\
\hline Male & 0.68 & $\begin{array}{l}\text { Permanent } \\
\text { contract }\end{array}$ & 0.94 & $\begin{array}{l}15-49 \\
\text { employees }\end{array}$ & 0.25 & $\begin{array}{l}\text { Local } \\
\text { unemployment } \\
\text { rate }\end{array}$ & $\begin{array}{l}7.55 \\
(2.56)\end{array}$ \\
\hline Age $<30$ years & 0.16 & Part-time & 0.12 & $\begin{array}{l}\text { 50-99 } \\
\text { employees }\end{array}$ & 0.14 & $\begin{array}{l}\text { Better wages in } \\
\text { the sector than in } \\
\text { the firm }\end{array}$ & $\begin{array}{l}1 \\
(0.16)\end{array}$ \\
\hline Age $30-49$ years & 0.64 & $\begin{array}{l}\text { Tenure (in } \\
\text { months) }(12-590)\end{array}$ & $\begin{array}{l}123.4 \\
(99)\end{array}$ & $\begin{array}{l}\text { 100-249 } \\
\text { employees }\end{array}$ & 0.20 & $\begin{array}{l}\text { Growth of } \\
\text { employment in the } \\
\text { sector }\end{array}$ & $\begin{array}{l}0.29 \\
(2.91)\end{array}$ \\
\hline $\begin{array}{l}50 \text { years and } \\
\text { more }\end{array}$ & 0.20 & $\begin{array}{l}\text { Experience (in } \\
\text { years) }(0-50)\end{array}$ & $\begin{array}{l}19.53 \\
(10.5)\end{array}$ & $\begin{array}{l}250 \text { employees } \\
\text { and more }\end{array}$ & 0.41 & $\begin{array}{l}\text { Firm in the upper } \\
\text { third of } \\
\text { employment } \\
\text { growth }\end{array}$ & 0.30 \\
\hline Luxembourgish & 0.18 & Union & 0.32 & Manufacturing & 0.15 & Matching quality & \\
\hline German & 0.13 & $\begin{array}{l}\text { Professionals and } \\
\text { managers }\end{array}$ & 0.20 & Construction & 0.15 & $\begin{array}{l}\text { Training paid } \\
\text { alone }\end{array}$ & 0.06 \\
\hline Belgian & 0.15 & $\begin{array}{l}\text { Associate } \\
\text { professionals }\end{array}$ & 0.20 & $\begin{array}{l}\text { Trade, } \\
\text { accommodation } \\
\text { and food serv. }\end{array}$ & 0.19 & $\begin{array}{l}\text { Too high } \\
\text { educational level }\end{array}$ & 0.27 \\
\hline French & 0.32 & $\begin{array}{l}\text { Administrative } \\
\text { and clerical }\end{array}$ & 0.15 & $\begin{array}{l}\text { Transportation } \\
\text { and storage }\end{array}$ & 0.09 & Too low skills & 0.60 \\
\hline Portuguese & 0.14 & $\begin{array}{l}\text { Sales and service } \\
\text { personnel }\end{array}$ & 0.11 & $\begin{array}{l}\text { IT and } \\
\text { communication }\end{array}$ & 0.06 & $\begin{array}{l}\text { Too low ICT } \\
\text { skills }\end{array}$ & 0.08 \\
\hline Other nationality & 0.08 & Craft & 0.15 & Finance & 0.19 & $\begin{array}{l}\text { Too high ICT } \\
\text { skills }\end{array}$ & 0.19 \\
\hline $\begin{array}{l}\text { Living with } \\
\text { partner }\end{array}$ & 0.80 & Plant operatives & 0.09 & Other services & 0.17 & Instruments & \\
\hline Child & 0.59 & $\begin{array}{l}\text { Non-qualified } \\
\text { operatives }\end{array}$ & 0.10 & $\begin{array}{l}\text { Adverse working } \\
\text { conditions }\end{array}$ & & $\begin{array}{l}\text { Task discretion } \\
(0-30)\end{array}$ & 17.89 \\
\hline $\begin{array}{l}\text { Education less } \\
\text { than secondary }\end{array}$ & 0.18 & & & $\begin{array}{l}\text { Harm working } \\
\text { conditions }\end{array}$ & 0.33 & $\begin{array}{l}\text { Work dependence } \\
\text { with colleagues }\end{array}$ & 0.53 \\
\hline Secondary & 0.45 & & & $\begin{array}{l}\text { Scheduling } \\
\text { hazard }\end{array}$ & 0.29 & $\begin{array}{l}\text { Feedback from the } \\
\text { superior }\end{array}$ & 0.58 \\
\hline Post-secondary & 0.37 & & & Accident risk & 0.37 & $\begin{array}{l}\text { Quintile of hourly } \\
\text { wage (1-5) }\end{array}$ & $\begin{array}{l}3.02 \\
(1.40)\end{array}$ \\
\hline \multirow[t]{2}{*}{$\begin{array}{l}\text { Commuting time } \\
(1-8)\end{array}$} & $\begin{array}{l}4.13 \\
(1.96)\end{array}$ & & & $\begin{array}{l}\text { Feeling of being } \\
\text { neglected by the } \\
\text { hierarchy }\end{array}$ & 0.16 & & \\
\hline & & & & Discrimination & 0.13 & & \\
\hline
\end{tabular}

Observations $\quad 14,248$

Notes: Weighted statistics. Standard deviations are shown in parentheses for non-binary variables. Variables omitted in the estimations are in italic.

Table A6. Validity of the exclusion restriction for the Model 2 - specification 2 of Table 2.

\begin{tabular}{lll}
\hline & Controlled motivation & Autonomous motivation \\
\hline First-stage F test & 19.07 & 21.98 \\
p-value & $(0.000)$ & $(0.000)$ \\
\hline Over-identification test - Hansen J statistic & 0.870 &
\end{tabular}


Chi-square

$(0.6471)$

Notes: These tests are given as indicative as they are based on 2SLS linear probability models and not on the estimation strategy used to obtain the results presented in Table 2 .

Table A7. HRM, ICT, work motivation and on-the-job search - all results.

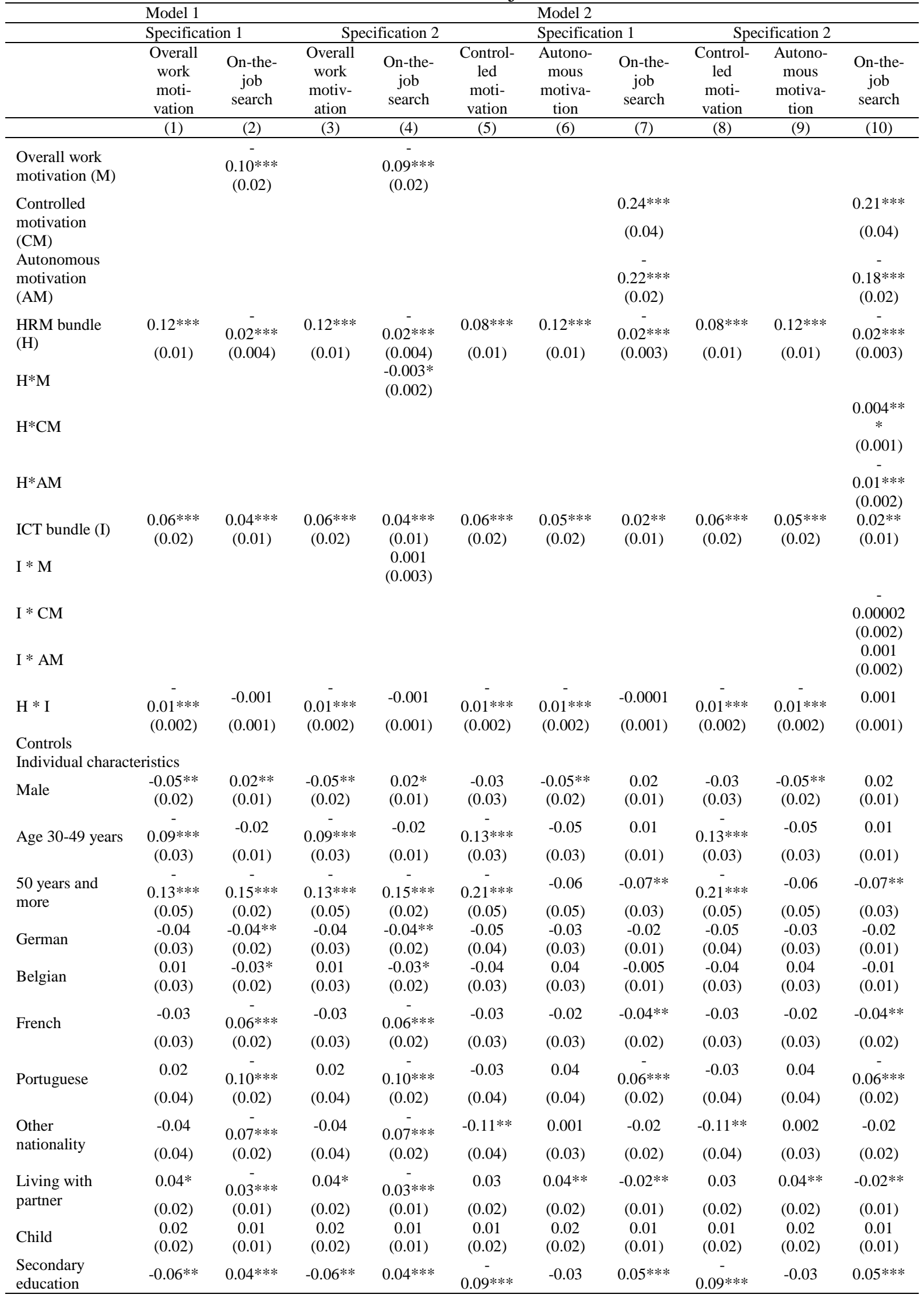




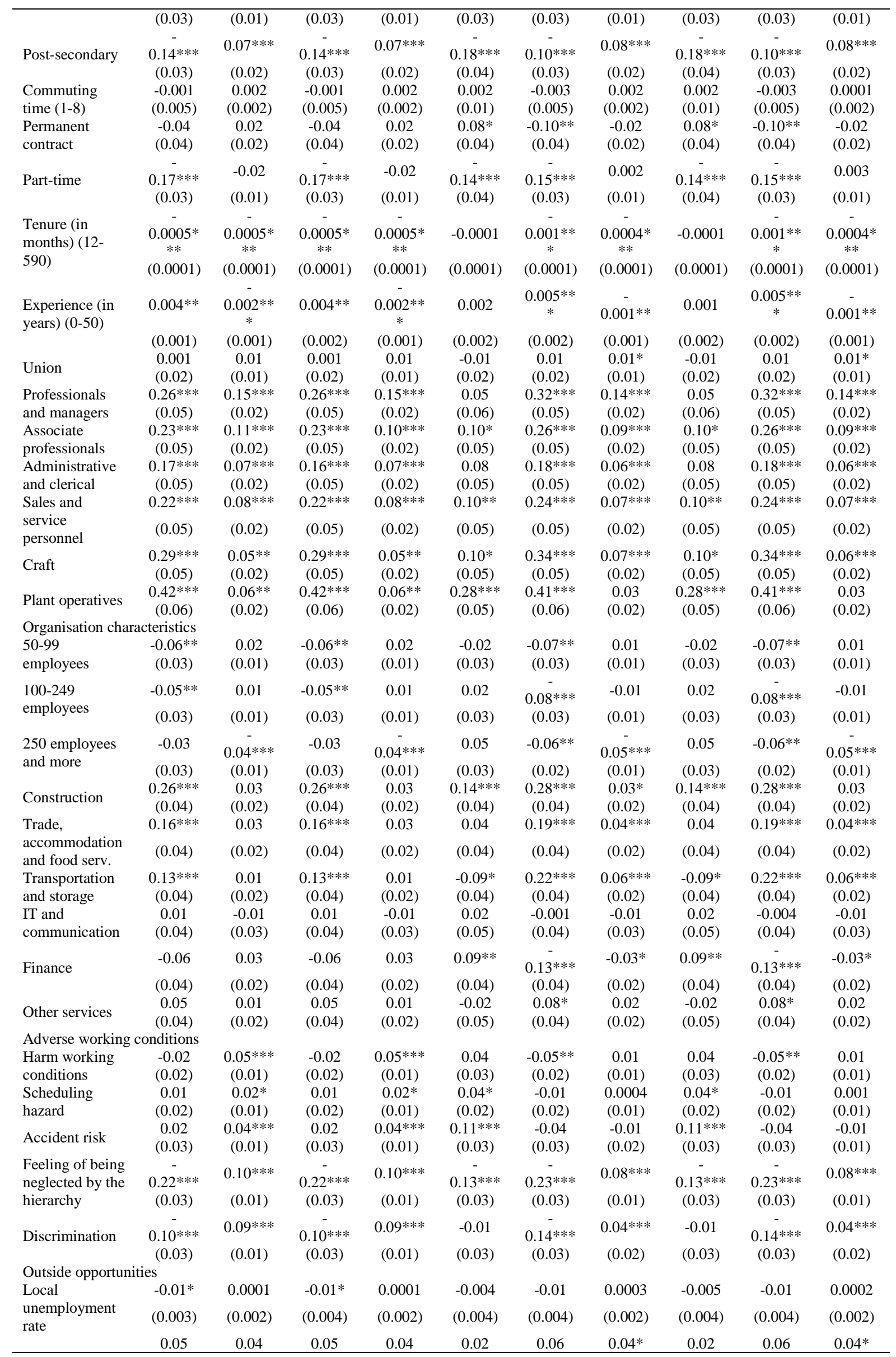




\begin{tabular}{|c|c|c|c|c|c|c|c|c|c|c|}
\hline $\begin{array}{l}\text { Better wages in } \\
\text { the sector than } \\
\text { in the firm }\end{array}$ & $(0.06)$ & $(0.03)$ & $(0.06)$ & $(0.03)$ & $(0.07)$ & $(0.05)$ & $(0.02)$ & $(0.07)$ & $(0.05)$ & $(0.02)$ \\
\hline \multirow{2}{*}{$\begin{array}{l}\text { Growth of } \\
\text { employment in } \\
\text { the sector }\end{array}$} & -0.003 & $0.004^{*}$ & -0.003 & $0.004^{*}$ & 0.01 & -0.01 & -0.0002 & 0.01 & -0.01 & -0.0002 \\
\hline & $(0.01)$ & $(0.002)$ & $(0.01)$ & $(0.002)$ & $(0.005)$ & $(0.01)$ & $(0.002)$ & $(0.005)$ & $(0.01)$ & $(0.002)$ \\
\hline \multirow{2}{*}{$\begin{array}{l}\text { Firm in the } \\
\text { upper third of } \\
\text { employment } \\
\text { growth }\end{array}$} & 0.02 & -0.01 & 0.02 & -0.01 & -0.01 & 0.03 & -0.001 & -0.01 & 0.03 & -0.001 \\
\hline & $(0.02)$ & $(0.01)$ & $(0.02)$ & $(0.01)$ & $(0.02)$ & $(0.02)$ & $(0.01)$ & $(0.02)$ & $(0.02)$ & $(0.01)$ \\
\hline \multicolumn{11}{|l|}{ Matching quality } \\
\hline $\begin{array}{l}\text { Training paid } \\
\text { alone }\end{array}$ & $\begin{array}{c}0.07 * * \\
(0.03)\end{array}$ & $\begin{array}{c}0.09 * * * \\
(0.02)\end{array}$ & $\begin{array}{c}0.07 * * \\
(0.03)\end{array}$ & $\begin{array}{c}0.09 * * * \\
(0.02)\end{array}$ & $\begin{array}{c}0.03 \\
(0.04)\end{array}$ & $\begin{array}{c}0.07 * * \\
(0.03)\end{array}$ & $\begin{array}{c}0.07 * * * \\
(0.02)\end{array}$ & $\begin{array}{c}0.03 \\
(0.04)\end{array}$ & $\begin{array}{c}0.07 * * \\
(0.03)\end{array}$ & $\begin{array}{c}0.07 * * * \\
(0.02)\end{array}$ \\
\hline $\begin{array}{l}\text { Too high } \\
\text { educational } \\
\text { level }\end{array}$ & $\begin{array}{c}- \\
0.20 * * * \\
(0.02)\end{array}$ & $\begin{array}{c}0.07 * * * \\
(0.01)\end{array}$ & $\begin{array}{c}- \\
0.20 * * * \\
(0.02)\end{array}$ & $\begin{array}{c}0.07 * * * \\
(0.01)\end{array}$ & $\begin{array}{c}- \\
0.07 * * * \\
(0.02)\end{array}$ & $\begin{array}{c}- \\
0.23 * * * \\
(0.02)\end{array}$ & $\begin{array}{l}0.03 * * \\
(0.01)\end{array}$ & $\begin{array}{c}- \\
0.07 * * * \\
(0.02)\end{array}$ & $\begin{array}{c}- \\
0.23 * * * \\
(0.02)\end{array}$ & $\begin{array}{l}0.03 * * \\
(0.01)\end{array}$ \\
\hline Too low skills & $\begin{array}{c}0.12 * * * \\
(0.02)\end{array}$ & $\begin{array}{c}0.03^{* * *} * \\
(0.01)\end{array}$ & $\begin{array}{c}0.12 * * * \\
(0.02)\end{array}$ & $\begin{array}{c}0.03 * * * \\
(0.01)\end{array}$ & $\begin{array}{c}0.08 * * * \\
(0.02)\end{array}$ & $\begin{array}{c}0.12 * * * \\
(0.02)\end{array}$ & $\begin{array}{c}0.02 * * \\
(0.01)\end{array}$ & $\begin{array}{c}0.08 * * * \\
(0.02)\end{array}$ & $\begin{array}{c}0.12 * * * \\
(0.02)\end{array}$ & $\begin{array}{c}0.02 * * \\
(0.01)\end{array}$ \\
\hline $\begin{array}{l}\text { Too low ICT } \\
\text { skills }\end{array}$ & $\begin{array}{c}-0.0003 \\
(0.03)\end{array}$ & $\begin{array}{c}0.05^{* * * *} \\
(0.01)\end{array}$ & $\begin{array}{c}-0.0003 \\
(0.03)\end{array}$ & $\begin{array}{c}0.05 * * * \\
(0.01)\end{array}$ & $\begin{array}{l}-0.01 \\
(0.03)\end{array}$ & $\begin{array}{c}0.01 \\
(0.03)\end{array}$ & $\begin{array}{c}0.04 * * * \\
(0.01)\end{array}$ & $\begin{array}{l}-0.01 \\
(0.03)\end{array}$ & $\begin{array}{c}0.01 \\
(0.03)\end{array}$ & $\begin{array}{c}0.04 * * * \\
(0.01)\end{array}$ \\
\hline $\begin{array}{l}\text { Too high ICT } \\
\text { skills }\end{array}$ & $\begin{array}{l}-0.03 * \\
(0.02)\end{array}$ & $\begin{array}{c}0.03 * * * \\
(0.01)\end{array}$ & $\begin{array}{l}-0.03 * \\
(0.02)\end{array}$ & $\begin{array}{c}0.03 * * * \\
(0.01)\end{array}$ & $\begin{array}{c}-0.05 * * \\
(0.02)\end{array}$ & $\begin{array}{l}-0.02 \\
(0.02)\end{array}$ & $\begin{array}{c}0.03 * * * \\
(0.01)\end{array}$ & $\begin{array}{c}-0.05^{* *} * \\
(0.02)\end{array}$ & $\begin{array}{l}-0.02 \\
(0.02)\end{array}$ & $\begin{array}{c}0.03 * * * \\
(0.01)\end{array}$ \\
\hline \multicolumn{11}{|l|}{ Instruments } \\
\hline Task discretion & $0.03 * * *$ & & $0.03 * * *$ & & $0.02 * * *$ & $0.03 * * *$ & & $0.02 * * *$ & $0.03 * * *$ & \\
\hline$(0-30)$ & $(0.002)$ & & $(0.002)$ & & $(0.002)$ & $(0.001)$ & & $(0.001)$ & $(0.001)$ & \\
\hline \multirow{2}{*}{$\begin{array}{l}\text { Work } \\
\text { dependence } \\
\text { with colleagues }\end{array}$} & 0.01 & & 0.01 & & $0.09 * * *$ & -0.02 & & $0.09 * * *$ & -0.02 & \\
\hline & $(0.02)$ & & $(0.02)$ & & $(0.02)$ & $(0.02)$ & & $(0.02)$ & $(0.02)$ & \\
\hline $\begin{array}{l}\text { Feedback from } \\
\text { the superior }\end{array}$ & $\begin{array}{c}0.13 * * * \\
(0.02)\end{array}$ & & $\begin{array}{c}0.13 * * * \\
(0.02)\end{array}$ & & $\begin{array}{c}0.11 * * * \\
(0.02)\end{array}$ & $\begin{array}{c}0.12 * * * \\
(0.02)\end{array}$ & & $\begin{array}{c}0.11 * * * \\
(0.02)\end{array}$ & $\begin{array}{c}0.12 * * * \\
(0.02)\end{array}$ & \\
\hline \multirow{2}{*}{$\begin{array}{l}\text { Quintile of } \\
\text { hourly wage (1- } \\
5)\end{array}$} & $0.04 * * *$ & & $0.04 * * *$ & & $0.05 * * *$ & $0.04 * * *$ & & $0.05 * * *$ & $0.04^{* * *}$ & \\
\hline & $(0.01)$ & & $(0.01)$ & & $(0.01)$ & $(0.01)$ & & $(0.01)$ & $(0.01)$ & \\
\hline Constant & $\begin{array}{c}- \\
1.62 * * * \\
(0.11)\end{array}$ & & $\begin{array}{c}- \\
1.62 * * * \\
(0.11) \\
\end{array}$ & & $\begin{array}{c}- \\
1.15 * * * \\
(0.11)\end{array}$ & $\begin{array}{c}- \\
1.59 * * * \\
(0.10)\end{array}$ & & $\begin{array}{c}- \\
1.15 * * * \\
(0.11)\end{array}$ & $\begin{array}{c}- \\
1.59 * * * \\
(0.10)\end{array}$ & \\
\hline $\begin{array}{l}\text { Rho M-job } \\
\text { search }\end{array}$ & & $\begin{array}{l}0.126 * * \\
(0.0509)\end{array}$ & & $\begin{array}{l}0.126 \\
(0.056\end{array}$ & & & & & & \\
\hline $\begin{array}{l}\text { Rho CM-job } \\
\text { search }\end{array}$ & & & & & & \multicolumn{2}{|c|}{$\begin{array}{c}-0.573 * * * \\
(0.145)\end{array}$} & & $\begin{array}{r}-0.572 \\
(0.14\end{array}$ & \\
\hline Rho AM-job & & & & & & & $101 * *$ & & 0.0959 & \\
\hline search & & & & & & & $.0423)$ & & $(0.042$ & \\
\hline Rho CM - & & & & & & & $17 * * *$ & & $0.517 *$ & \\
\hline $\mathrm{AM}$ & & & & & & & $0113)$ & & $(0.011$ & \\
\hline $\log \mathrm{L}$ & & -25952.95 & & -2595 & & & 295.65 & & -43283 & \\
\hline Wald Chi 2 & & $847.79 * * *$ & & 7854.9 & & 14 & $9.11 * * *$ & & 14268 & \\
\hline Pseudo R2 & & 0.12 & & 0.12 & & & 0.09 & & 0.09 & \\
\hline Observations & & 14,248 & & 14,2 & & & 4,248 & & 14,24 & \\
\hline
\end{tabular}

Notes: Robust standard errors clustered at the level of working in the same organisation in parentheses. Weighted estimations. Columns (2), (4), (7) and (10) report average marginal effects; other columns report coefficients. Rho are correlations parameters between error terms of equations. * significant at $10 \%$;* significant at $5 \%$; *** significant at $1 \%$. 